Article

\title{
An Assessment of Airport Sustainability, Part 1-Waste Management at Copenhagen Airport
}

\author{
Glenn Baxter ${ }^{1}$, Panarat Srisaeng ${ }^{1}$ and Graham Wild ${ }^{2, *}$ (iD \\ 1 School of Tourism and Hospitality Management, Suan Dusit University, Hua Hin Campus, \\ Prachaup Khiri Khan 77110, Thailand; g_glennbax@dusit.ac.th (G.B.); panarat_sri@dusit.ac.th (P.S.) \\ 2 School of Engineering, RMIT University, Melbourne 3000, Victoria, Australia \\ * Correspondence: graham.wild@rmit.edu.au; Tel.: +61-3-9925-8051
}

Received: 14 December 2017; Accepted: 8 March 2018; Published: 15 March 2018

\begin{abstract}
Airports play a vital role in the air transport industry value chain, acting as the interface point between the air and surface transport modes. However, substantial volumes of waste are produced as a by-product of the actors' operations. Waste management is therefore becoming especially important to airports. Using a qualitative and quantitative case study research approach, this paper has examined the waste management strategies and systems at Copenhagen Airport, Scandinavia's major air traffic hub, from 1999 to 2016. The two major sources of waste at Copenhagen Airport are the waste generated from aircraft serving the airport and the waste arising from ground activities undertaken in the land and airside precincts. The growth in passengers and aircraft movements has had a concomitant impact on the volume of waste generated. Swept waste and sludge are processed by an external provider. Waste generated in the passenger terminals and the airport operator's facilities is handled at a central container station, where it is sorted for incineration, recycling or for landfill. The environmental impact of the waste produced at the airport is mitigated through the recycling of waste wherever possible.
\end{abstract}

Keywords: airport; construction waste; Copenhagen Airport; incinerated waste; landfill waste; recycling waste; waste disposal; waste management

\section{Introduction}

Airports play a vital role in the global air transport value chain, acting as the critical interface point between the surface-based and air transport modes. In addition to their aviation-related functions, airports are increasingly evolving, and many airports now have shopping and hotel complexes, conference facilities, logistics areas and intermodal public transport hubs [1]. However, with growing environmental pressures being placed on airports and airlines alike, all areas of the air transport industry have increasingly moved towards reducing their respective carbon 'footprints' [2]. Accordingly, airports are working to make themselves more environmentally friendly [3-5]. Environmental management plans and eco-friendly policies and strategies are therefore increasingly being adopted by airports all around the world [6]. The various activities that are performed at airports produce considerable volumes of waste [7-10]. Thus, the issue of waste management within airports is becoming especially important due to the very significant increases in passenger numbers [11] and the consequent volumes of waste that are generated.

One such airport that has sustainably managed its waste management is Copenhagen Airport, Denmark's busiest airport and Scandinavia's major air traffic hub. The airport operator, Copenhagen Airports A/S has defined and implemented a policy aimed at ensuring the sustainable development of the airport. In accordance with this policy, the airport aims to reduce the environmental impact of the airport waste wherever possible [12]. The objective of this paper is to analyse the waste management 
strategies at Copenhagen Airport, as well as the sources, types and volumes of waste generated at the airport, in addition to the methods used to mitigate the environmental impact of the waste produced at the airport. To achieve the study's objectives, the following research questions were examined:

1. What are the distinct types and quantities of waste generated at Copenhagen and have these changed over time?

2. What impact has the growth in passengers and aircraft movements had on the volumes of waste generated at Copenhagen Airport?

3. What type of waste management system has been implemented at Copenhagen Airport?

4. What systems are used to mitigate the impact of waste on the environment at Copenhagen Airport?

It is important to note at the outset that Denmark is viewed as being a developed economy [13], and thus, the case study takes a More Economically-Developed Country (MEDC) perspective.

The remainder of the paper is structured as follows. Section 2 reviews the literature on waste management at airports; the research methodology used to underpin the study is presented in Section 3; the case study of Copenhagen Airport's sustainable waste management follows in Section 4; Section 5 presents the findings of the study.

\section{Literature Review}

\subsection{Waste Management Hierarchy}

The waste management hierarchy proposes a ranking of waste disposal methods from most to least desirable in terms of environmental efficiency [10,14]. The waste hierarchy is as follows: reduce, re-use, recycle, recovery and disposal (Figure 1) [14]. This means that in the hierarchy, reducing waste should be the primary concern for a firm. There are two principles in achieving waste reduction: firstly, to reduce the volume generated and disposed of in landfills, thus reducing the deterioration of the environment, reducing the emissions generated from landfills and also saving energy and natural resources [15]; secondly, to adopt an effective system to manage all unavoidable waste. According to the waste management hierarchy, re-use and recycling are the best methods of dealing with unavoidable waste [10]. Re-using waste, wherever possible, is regarded as more preferable to recycling because the waste items do not need to be processed prior to being used again [16]. The next best disposal route is incineration, which can also be used as a means of generating energy, although there are some undesirable environmental effects. Finally, disposal in landfill sites is regarded as the least desirable option [10,17].

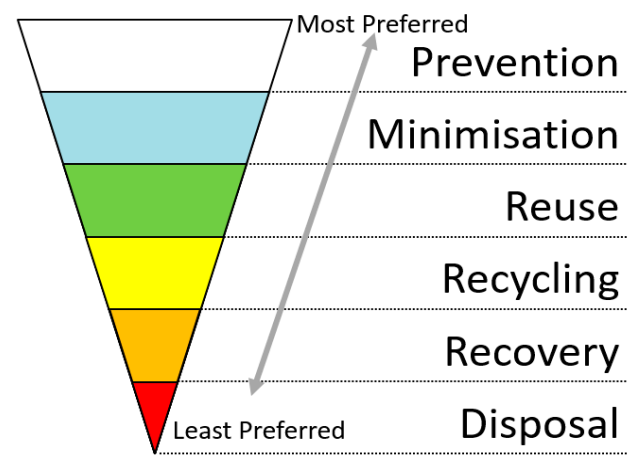

Figure 1. Waste management hierarchy. Source: adapted from [18].

\subsection{Sources of Airport Waste}

In addition to the waste that is generated from aircraft, airport waste is produced in airport offices, retail outlets, restaurants, restrooms and flight catering centres, from air cargo operations, 
maintenance facilities and areas and from landscaping, construction and demolition projects undertaken at the airport. Each of these areas creates discrete waste streams [19], all of which have the potential to generate substantial volumes of waste [20].

The waste generated at airports can be broadly divided into the waste generated by the landside activities undertaken at the airport, as well as the waste produced by the key stakeholders involved in the provision of the airport's airside area operations. Landside means those parts of an airport, as well as the adjacent terrain and buildings or portions thereof that are not in the airside precinct. Airside means the movement area of an airport, adjacent terrain and buildings/infrastructure, or portions, the access to which is restricted [21]. Table 1 summarizes the diverse types of wastes that are generated by the key stakeholders involved in the facilitation and handling of passengers and air cargo (where applicable) on the landside of an airport.

Table 1. Key airport landside actors and typical types of waste generated.

\begin{tabular}{|c|c|}
\hline Airport Stakeholder & Types of Waste Generated \\
\hline Airport Authority & $\begin{array}{l}\text { Food, paper, plastic (in many forms), aluminium cans, restaurant and } \\
\text { cafeteria grease and oil, electronics. Light bulbs, green waste from lawn } \\
\text { cutting and landscaping, general rubbish, airport construction waste: } \\
\text { concrete, asphalt, building materials, wood, soil, } \\
\text { construction equipment waste, regular rubbish items. }\end{array}$ \\
\hline Airlines & $\begin{array}{l}\text { Food and drink containers, newspapers and magazines, food waste } \\
\text { (from lounges/cafeterias), light bulbs, printer toner, paper, } \\
\text { documents and computer print outs. }\end{array}$ \\
\hline Airport Concessionaires and Shops & $\begin{array}{l}\text { Food, general rubbish, paper, toner cartridges, batteries, light bulbs, } \\
\text { plastic bottles, aluminium cans, packaging. }\end{array}$ \\
\hline Airport Hotel & $\begin{array}{l}\text { Food waste, paper, rags/cloth, light bulbs, napkins, packaging materials, } \\
\text { newspapers, green waste from lawn/plant care and landscaping. }\end{array}$ \\
\hline Car Parks & Food waste, waste paper. \\
\hline Cargo Terminal Operators & $\begin{array}{l}\text { Tyres, fluids, lights bulbs, batteries, wood and wooden pallets, } \\
\text { plastic wrapping material }{ }^{1} \text {, green waste from lawn/garden care and } \\
\text { landscaping, paper, computer printouts. }\end{array}$ \\
\hline Freight Forwarders & $\begin{array}{l}\text { Paper, toner cartridges, batteries, light bulbs, plastic, packaging, } \\
\text { aluminium cans and plastic bottles, food and general rubbish. }\end{array}$ \\
\hline Government Agencies & $\begin{array}{l}\text { Paper, toner cartridges, batteries, electronics, plastic bottles, } \\
\text { aluminium cans, food, general rubbish. }\end{array}$ \\
\hline Ground Handling Agent & $\begin{array}{l}\text { Paper, toner cartridges, lights bulbs, batteries, plastic, aluminium cans, } \\
\text { food and general rubbish. }\end{array}$ \\
\hline Ground Transport Interchange & $\begin{array}{l}\text { Food waste, waste paper, rags/cloth, newspapers, magazines, } \\
\text { green waste from lawn care and landscaping. }\end{array}$ \\
\hline Passengers, Meeters and Greeters & $\begin{array}{l}\text { Food, aluminium cans, plastic bottles, packaging, } \\
\text { newspapers, magazines. }\end{array}$ \\
\hline Railway Station & $\begin{array}{l}\text { Food waste, rag/cloth, newspapers, magazines, waste paper, } \\
\text { plastic bottles, metal drink cans. }\end{array}$ \\
\hline Rental Car Firms & $\begin{array}{l}\text { Paper, computer printouts, toner cartridges, batteries, light bulbs, } \\
\text { oils and greases, aluminium cans, general rubbish. }\end{array}$ \\
\hline Restaurants & $\begin{array}{l}\text { Retail and food and beverage waste, cardboard boxes, paper, } \\
\text { plastic items, packaging, food packaging, food wrappers, oils and } \\
\text { grease, aluminium cans, plastic bottles, plastic and glass containers. }\end{array}$ \\
\hline Taxi-Cab Holding Bays & $\begin{array}{l}\text { Food waste, waste paper, rags/cloth, green waste from lawn care } \\
\text { and landscaping. }\end{array}$ \\
\hline
\end{tabular}

${ }^{1}$ Packing material (plastic) is used in air cargo operations to prevent leakage and possible water damage to the contents of cargo pallets or in aircraft Unit Load Devices (ULDs). Aircraft unit load devices are pallets and containers that are used to carry air cargo, mail and passenger baggage on wide-body passenger and freighter aircraft [22]. Source: adapted from $[23,24]$. 
Table 2 shows the actors involved with the provision of passenger and aircraft-related functions on the airside of an airport and the types of waste generated from these operations. In addition to the passenger and aircraft-related waste, wastes are also generated from offices and from the concessionaires, for example duty-free shops and restaurants) operating at the airport.

Table 2. Key airport airside actors and typical types of waste generated.

\begin{tabular}{|c|c|}
\hline Airport Stakeholder & Types of Waste Generated \\
\hline Airport Authority & $\begin{array}{l}\text { Food, paper, plastic (in many forms), aluminium cans, restaurant and } \\
\text { cafeteria grease and oil, electronics. Light bulbs, green waste from lawn } \\
\text { cutting and landscaping, general rubbish, airport construction waste: } \\
\text { concrete, asphalt, building materials, wood, soil, construction } \\
\text { equipment waste, regular rubbish items. }\end{array}$ \\
\hline Aircraft Maintenance Firms & $\begin{array}{l}\text { Food, packaging, oils, greases, solvents, packaging, wooden pallets, } \\
\text { general rubbish. }\end{array}$ \\
\hline Airport Concessionaires and Shops & $\begin{array}{l}\text { Food, general rubbish, paper, toner cartridges, batteries, light bulbs, } \\
\text { plastic bottles, aluminium cans, packaging. }\end{array}$ \\
\hline Airport Fuel Farm and Suppliers & $\begin{array}{l}\text { Paper, toner cartridges, batteries, light bulbs, plastic bottles, } \\
\text { aluminium cans, food and general rubbish, oils and grease } \\
\text { from vehicles. }\end{array}$ \\
\hline Air Traffic Control (ATC) & $\begin{array}{l}\text { Paper, toner cartridges, computer printouts, light bulbs, batteries, } \\
\text { food and general waste, oils and greases from vehicles. }\end{array}$ \\
\hline Airlines & $\begin{array}{l}\text { Food and drink containers, newspapers and magazines, food waste } \\
\text { (from lounges/cafeterias), light bulbs, printer toner, paper, } \\
\text { documents and computer print outs, oils and greases from ground } \\
\text { service equipment and vehicles. }\end{array}$ \\
\hline Cargo Terminal Operators & $\begin{array}{l}\text { Tyres, fluids, lights bulbs, batteries, wood and wooden pallets, } \\
\text { plastic wrapping material, green waste from lawn/garden care and } \\
\text { landscaping, paper, computer printouts. }\end{array}$ \\
\hline Fixed Base Operator (FBO) & $\begin{array}{l}\text { Paper, toner cartridges, lights bulbs, batteries, plastic, aluminium cans, } \\
\text { food and general rubbish, oils and greases from ground } \\
\text { handling equipment. }\end{array}$ \\
\hline Flight Catering Centres and Kitchens & $\begin{array}{l}\text { Food and beverage waste, cardboard boxes, paper, plastic items, } \\
\text { packaging, food packaging, food wrappers, oils and grease, } \\
\text { aluminium cans, plastic bottles, plastic and glass containers. }\end{array}$ \\
\hline General Aviation/Business Jet Centre & $\begin{array}{l}\text { Paper, toner cartridges, batteries, electronics, plastic bottles, } \\
\text { aluminium cans, food, general rubbish, oils and grease from } \\
\text { equipment maintenance. }\end{array}$ \\
\hline Government Agencies & $\begin{array}{l}\text { Paper, toner cartridges, batteries, electronics, plastic bottles, } \\
\text { aluminium cans, food, general rubbish. }\end{array}$ \\
\hline Ground Equipment Maintenance Firms & $\begin{array}{l}\text { Paper, toner cartridges, light bulbs, plastic bottles and aluminium cans, } \\
\text { packaging, wooden pallets, oils and greases. }\end{array}$ \\
\hline Ground Handling Agent & $\begin{array}{l}\text { Paper, toner cartridges, lights bulbs, batteries, plastic, aluminium cans, } \\
\text { food and general rubbish, oils and greases from ground } \\
\text { handling equipment. }\end{array}$ \\
\hline Ground Transport Interchange & $\begin{array}{l}\text { Food waste, waste paper, rags/cloth, newspapers, magazines, } \\
\text { green waste from lawn care and landscaping. }\end{array}$ \\
\hline Passengers & $\begin{array}{l}\text { Food, aluminium cans, plastic bottles, packaging, } \\
\text { newspapers, magazines. }\end{array}$ \\
\hline Restaurants & $\begin{array}{l}\text { Retail and food and beverage waste, cardboard boxes, paper, } \\
\text { plastic items, packaging, food packaging, food wrappers, oils and } \\
\text { grease, aluminium cans, plastic bottles, plastic and glass containers. }\end{array}$ \\
\hline
\end{tabular}

While most of the waste is generated by the airlines serving the airport, it is normally the airport operators who have the overall responsibility for waste management for all the airport-related activities. Most of the individual firms operating at the airport, particularly the airlines, do not have sufficient 
space for waste management facilities. Furthermore, there are cost economies of scale to be gained through communal recycling and other waste management procedures [25].

\subsection{Solid and Hazardous Waste Produced at Airports}

Waste management at airports compromises both solid and hazardous waste [26,27]. It has been estimated that airlines and retail and restaurant tenants produce around 90 percent of the waste at a typical airport [28].

There are seven discrete types of waste generated at airports can be divided into seven discrete types of waste: (1) municipal solid waste; (2) Construction and demolition waste; (3) green waste; (4) food remediation waste; (5) waste from aircraft flights (deplaned waste); (6) lavatory waste; and (7) spill clean-up and remediation waste [3,24].

- Municipal Solid Waste (MSW) compromises everyday items that are used and then subsequently discarded. These include items such as product packaging, furniture, clothing, bottles, food scraps and newspapers [3,9]. The final disposal of MSW by land-filling or open-dumping represents an environmental burden [29].

- Construction and Demolition waste (C\&D) is any non-hazardous solid waste produced from land clearing, excavation and/or the construction, demolition, renovation or repair of structures, roads and utilities at an airport. C\&D waste commonly compromises concrete, wood, metals, drywall, carpet, plastic, pipes, land clearing debris, cardboard and salvaged building components. In some cases, $C \& D$ waste may be subject to specific requirements, such as, tar impregnated roofing materials [3,9]. Solid waste is generated at airports during the construction of facilities (demolition and construction debris), operations (passengers in the airport terminals and on aircraft) and during maintenance activities (landscape debris, light bulbs, and so forth) [30].

- Green waste is categorized as MSW and may also referred to as "yard waste". The green waste generated at airports compromises tree, shrub and grass clippings, leaves, weeds, small branches, seeds, pods and similar debris generated from the airport's landscape maintenance activities.

- Food remediation waste is food that has not been consumed or is the waste generated and discarded during food preparation activities from in-flight kitchens.

- Deplaned aircraft waste is waste originating from aircraft flights. These waste materials include bottles and cans, newspaper and mixed paper, plastic cups and service ware, food waste, food soiled paper, as well as paper towels $[3,9,23]$. The volume and characteristics of waste generated on an aircraft are dependent on the length of the flight [31].

- Lavatory waste is a form of special waste and is generated when the lavatory tanks of the aircraft are emptied and pumped into a lavatory service vehicle. Once the aircraft's lavatory tanks are emptied, the lavatory tanks are refilled with a mixture of water and a disinfecting concentrate. Importantly, lavatory waste can be comprised of chemicals and potential enteric pathogens, and these can present significant risks to the environment and human health if they are not handled in an appropriate manner [24] (p. 2).

- Spill clean-up and remediation wastes are another form of special waste. These materials are generated during the clean-up of spills and/or the remediation of contamination from various types of on-airport sites, for instance, storage tanks, oil and gas production, vehicular leaks and spills from maintenance activities, and so forth $[3,24]$.

Environmental concerns related to solid waste include the volume of waste generated at the airport and waste, which requires disposal in landfills, as well as the location of the landfills in relation to airport runways and flight paths [32]. Accordingly, to minimise the negative impact on the environment from the disposal of waste, it is necessary for airports to identify ways to decrease the quantity of waste particularly through recycling, composting, reuse and introduction of wasteless technologies [32] (p. 538). The objective of waste management is therefore to reduce the volume of waste produced, thereby reducing disposal costs and, hence, the environmental impact of the 
airport [33]. In addition, social costs will be decreased in terms of residential communities near waste landfill sites and incinerators [11]. Many airports around the world now have recycling initiatives in place $[25,31]$.

Hazardous waste may be present at airports due to aircraft refuelling, aircraft maintenance activities (if they are conducted at the airport), rental car maintenance (waste oil), emergency power generators and other activities. Hazardous waste could also be present due to past activities that may have contaminated the soil or water. Furthermore, hazardous waste being transported by aircraft or vehicle onto airport property may have entered the airport's environment [30]. Some of this hazardous waste can pose a threat to human health and the environment if it is not handled in specific and safe ways [34].

\subsection{Airport Waste Management Systems}

Airports need to develop a waste management system that incorporates a range of measures including source separation and recycling of waste on the airport site, waste minimization, a charging regime for airport waste, the re-use of equipment and material whenever possible and the promotion and usage of products that are renewable and have the least environmental impact [7] (p. 77). Recycling programs should target airlines, retail and restaurant tenants, as these two sectors typically account for the largest amount of waste produced at an airport [28].

Waste mitigation measures form part of the airport waste management system, which are in place at many airports around the world, for example, Copenhagen Airport, Hong Kong International Airport, London Stansted Airport, Osaka's Kansai International Airport, Oslo Airport Gardermoen and San Francisco International Airport. The airport waste management system will typically be designed and operated in accordance with the applicable regulatory framework. This especially applies to the storage and disposal of waste in dedicated areas that cannot be used for other, more profitable activities. The airport waste management system normally includes the identification of the various waste sources, facilities, equipment and infrastructure required to deal with the different types and volumes of waste and finally the efficiency and effectiveness of the waste collection, storage, recycling and waste disposal [35].

An efficient and effective airport waste management system normally implies waste avoidance, waste minimisation and waste disposal. This will involve the separation (sorting) of the waste at airport's waste collection points, that is at the source, into solid and liquid, hazardous and non-hazardous waste, a reduction in the generated waste volumes, continuous increase in reuse, recycling and reprocessing of wastes and permanent improvement in airport waste management practices. Recycling may involve the conversion of waste into energy through thermal treatment or incineration (processing) [36,37].

There are three key waste disposal options available to airports [38].

1. Recycling: with this option the waste fraction is utilized again to produce raw materials that can be used for making new products or new forms of energy [39]. The types of waste that can be recycled include paper, card board, glass, plastics and metal [40,41];

2. Incineration: with this option, the waste fraction is incinerated. Incineration is defined as "a controlled combustion process for reducing solid, liquid, or gaseous combustible wastes primarily to carbon dioxide, water vapour, other gases and a relatively small, non-combustible residue, that can be further processed or land-filled in an environmentally acceptable manner" [42] (p. 3). An option is for the waste to be incinerated in a Combined Heat Power plant (CHP) that produces heat and/or electricity [43,44];

3. Landfill: waste that is not suitable for recycling or incineration will be deposited in a landfill. In many cases, it may be necessary to pre-treat the rubbish to remove hazardous substances [40] or to reduce the volume of waste to be sent to the landfill. 


\subsection{Airport Centralised or De-Centralised Waste Management Systems}

Airports can operate either centralised, de-centralised waste management systems or a combination of both procedures [3,32]. Centralized waste management systems will have a single waste management point for all airport terminal and aircraft waste except for flight catering centres, which often manage their own waste $[19,31]$.

In the case of airports that utilize centralized waste management systems, the airport authorities provide waste and recycling receptacles for use by the airport tenants and airlines [19]. A centralised waste management system (centralized collection and sorting) requires high investment and staff costs but is considered tidier and provides better separation of individual fractions and, therefore, provides better opportunities for negotiations with consumers of classified waste [31]. Furthermore, although a centralised system requires higher levels of coordination between the airport authority, tenants/concessionaire and airlines, the volume of waste handled under a single centralized contract is larger. Hence, due to the volume of waste that is generated from a single contract, an airport authority is in a more advantageous position to realize favourable economies of scale and thereby can negotiate lower per-tonne (ton) disposal and recycling costs with waste handling providers. The other advantages of a centralized waste management system for airports are:

- Centralised coordination of waste haulage and container maintenance results in less truck traffic on the airfield, less fuel usage and a reduced risk of airfield collisions;

- Greater control by the airport authority over the type, placement and maintenance of compactors and dumpsters saves space whilst also eliminating the requirement for each airline to have its own containers;

- Airlines that only produce small volumes of waste can recycle it with fewer overhead costs; and by directly billing tenants and airlines for waste management services, the airport authority can develop incentives to promote waste recycling [19] (p. 3).

Decentralised waste collection permits certain kinds of waste, for example paper and cardboard cartons, to be separated at each location [32]. In a decentralised waste management system, the airport authority, terminal tenants (concessionaires), airlines and flight catering firms, for example, will each have independent waste management contracts. From an airport management perspective, a decentralized waste management system enables an airport authority to minimize its obligations to coordinate the firms or agencies operating at the airport. In addition, it also enables each firm and agency operating at the airport to control their own waste management contract. Notwithstanding, decentralization does have some disadvantages:

- The system may be less efficient because more dumpsters than necessary may be used to handle the quantity of waste that is being disposed;

- It introduces the possibility of improper dumping in another airline's dumpster;

- Quantifying and tracking the amount of waste generated and recycled at an airport becomes more complicated; and

- Achieving the scale necessary to make recycling more economical for any single tenant is more difficult [19] (p. 5).

\subsection{Waste Management Regulatory Frameworks}

In many countries, there are legislative provisions as to how airports should deal with waste and materials. These regulations and legislation normally define how wastes should be stored, collected, treated and/or disposed of. Airports are also confronted with specific operating restrictions due to the nature of the air transport business. For example, airports are required to incinerate or arrange the transfer to a controlled landfill site for all "international" food waste from aircraft. In addition, the transfer of waste between the airport airside and landside can be problematic due to security, customs and insurance restrictions [25]. 


\section{Research Method}

A qualitative longitudinal approach was used in the study $[45,46]$. This methodology was chosen to build a theory [47], specifically of airport waste management. Copenhagen Airport was selected for the study due to the availability of waste related data covering the period 1999 to 2016 . The airport was also chosen for the study due to its long history of sustainable waste management and its role as a major hub airport in Scandinavia. Data for the study were obtained from a range of documents, company materials available on the internet and records as sources of case evidence. Documents included Copenhagen Airports A/S annual environmental reports, Copenhagen Airports $\mathrm{A} / \mathrm{S}$ group annual reports, press releases and the airport's websites. The study therefore used secondary data. The three principles of data collection as suggested by Yin [48] were followed: the use of multiple sources of case evidence, creation of a database on the subject and the establishment of a chain of evidence.

The qualitative document analysis process utilized followed the six phases identified by O'Leary [49] (p. 179). The documents collected for the study were examined according to four criteria: authenticity, credibility, representativeness and meaning [50,51].

The qualitative data used in the study were based on actual weights as published by Copenhagen Airports A/S. The data were entered into an Excel database, from which the quantitative analysis was conducted. Following the recommendations of Plewa, Jr. and Friedlob [52], Sinha [53] and Patel [54], the annual changes (\%) in the total waste, as well as the distinct types of waste produced at Copenhagen Airport were examined using the common size horizontal analysis method. The base year selected for this quantitative analysis was 1999.

\section{Results and Discussion}

\subsection{Copenhagen Airport: A Brief Overview}

Copenhagen Airport is in Kastrup, around $11 \mathrm{~km}$ southwest of downtown Copenhagen. The airport is Scandinavia's major airport acting as the transfer point for air traffic travelling between other parts of the world and the many national and regional airports located in Scandinavia, as well as the area south of the Baltic Sea. The airport also functions as the hub for SAS Scandinavian Airlines and is therefore one of the Star Alliance hubs [55]. Star Alliance is a network of 28 international airlines that provide services to a total of 1300 airport in 191 countries [56]. Copenhagen Airports A/S (CPH) is the listed company that operates both Copenhagen and Roskilde Airports. There are more than 700 companies located at Copenhagen Airport. These companies have a total work force of around 23,000 employees [57]. Around eighty airlines operate 726 arrival and departures flight per day from the airport. Direct flights are operated to 165 destinations, including 36 long-haul destinations [58].

The airport area, which occupies an area of around $11.8 \mathrm{~km}^{2}$, has four discrete geographical sections: Located in the North Area are the airport's three passenger terminals, a railway station, a car park, a police station and other administrative functions. The Zurich, Switzerland-based Gate Gourmet flight catering facilities, the SAS Cargo Center and SAS's technical area (which includes four large aircraft maintenance hangars) are also located in the North Area. Cargo terminals for DHL Express, a major global express cargo firm based in Bonn, Germany and SAS, the Veterinary and Customs Centre, air freight forwarding firms and the LSG Sky Chefs catering facilities are in the airport's East Area. The technical bases for My Travel, Sterling, Danish Air Transport and North Star are based in the airport's South Area precinct. The West Area of the airport contains Naviair (Denmark's Air Navigation Service Provider), as well as Copenhagen Airport's technical maintenance facilities. Copenhagen Airport's runway system comprises a main system (direction 22R/04L and 22L/04R) with two parallel runways for aircraft take-offs and landings ( 3500 and $3300 \mathrm{~m}$ long), as well as a 2800-m cross-runway (direction 12/30). The airport has a total of 108 stands: 9 domestic stands, 43 international stands with passenger loading bridges, 54 remote stands and 2 helicopter stands [55]. 
Copenhagen Airport is a full member of the Nordic Initiative for Sustainable Aviation (NISA) and has defined and implemented an Environmental Management System (EMS) that is aligned with world best practice. The airport is accredited to Level 3 (Optimisation level) of the Airports Council International (ACI) Airport Carbon Accreditation scheme [59]. The Airport Carbon Accreditation scheme was established in 2009 by the Airports Council International, the world's peak airport body. It is based on a four-level system whereby accreditation is awarded based on an airport operator's ability to reduce its carbon footprint. The names applied to each level of the programme are: (1) mapping; (2) reduction; (3) optimization; and (4) neutrality. The optimization level recognizes airports that have engaged and have been able to reduce the emissions from third parties operating on the airport campus; these include airlines, ground handling agents and flight catering firms [60].

Copenhagen Airport A/S (CPH) is the operator of Copenhagen and Roskilde Airports. The CPH environmental policies and work ensures that both of their airports are operated and developed in a responsible manner and which enables the company to continuously improve its environmental results. This applies to the global environment, where the company is working to reduce the airport's $\mathrm{CO}_{2}$ emissions, as well the local environment, where it is endeavouring to mitigate the impacts of waste (as well as noise, air pollution, soil and water pollution). Copenhagen Airports A/S is only responsible for the activities that are under its direct control; however, the company aims as far as possible to influence activities that are beyond its direct control, by working closely with its business partners and customers [61].

Figure 2 shows the total annual passenger traffic (domestic and international) and the annual percentage (\%) change relative to the base year (1999) at Copenhagen Airport from 1999 to 2016. We notice two important down turns in passenger demand, first following the 11 September 2001 incident in the United States and the associated war on terrorism that followed. The more significant decline is in 2009 following the 2008 Global Financial Crisis (GFC). This is more significant as air traffic demand is strongly linked to economic activity. As can be observed in Figure 2, the annual volumes of enplaned passengers increased from 2003 to 2008 . The decline in 2009 can be contributed to the impact of the GFC on airline traffic. From 2009 to 2016, the annual volumes of enplaned passengers have exhibited strong annual growth rates.

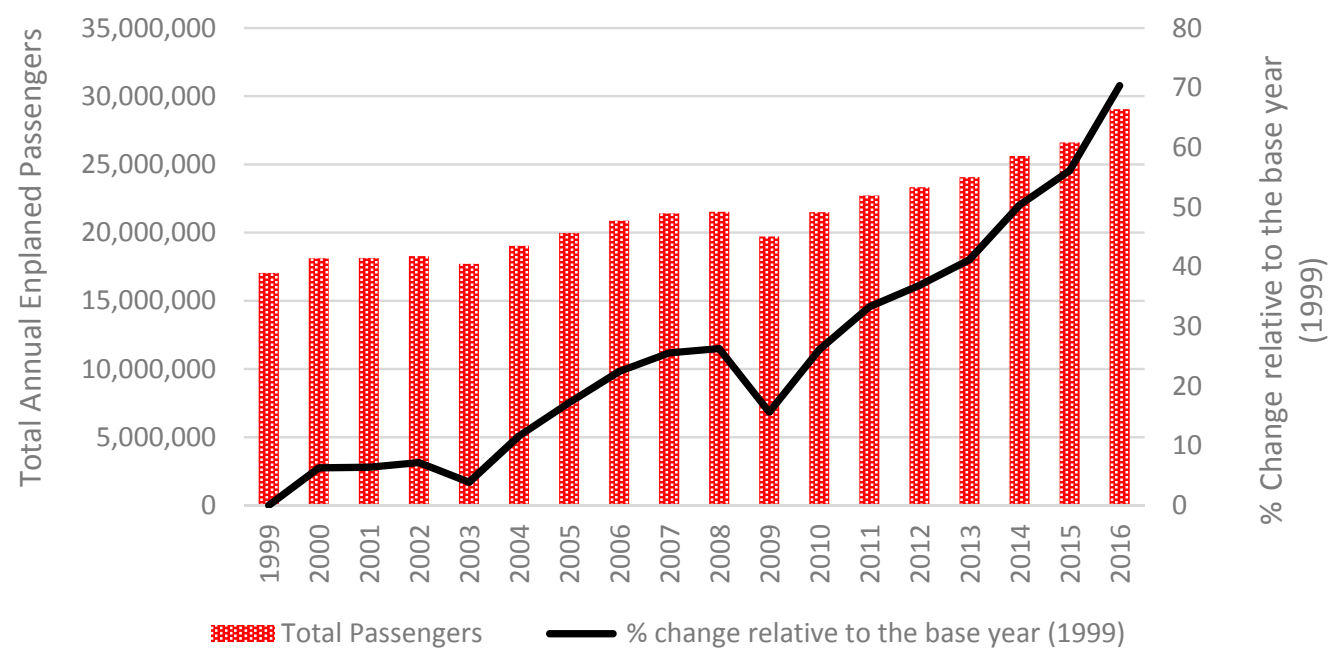

Figure 2. Copenhagen Airport's total annual enplaned passengers (domestic and international) and the annual percentage (\%) change relative to the base year (1999): 1999 to 2016. Source: data derived from $[12,40,61-64]$.

\subsection{Copenhagen Airports A/S Environmental and Regulatory Framework}

Denmark has been a member of the European Union (EU) since 1973 [65]. The EU Directive 2008/98/EC on waste (Waste Framework Directive) sets the basic concepts and definitions related to 
waste management. The directive sets the definitions of waste, recycling, recovery and, furthermore, it explains when waste ceases to be waste and becomes a secondary raw material. This is the so-called end-of-waste criteria. The waste directive also distinguishes between waste and by-products. The Directive lays down some basic waste management principles: Most importantly, the directive requires that waste be managed without endangering human health and harming the environment and without risk to water, air, soil, plants or animals, without causing a nuisance through noise or odours and without adversely affecting the countryside or places of special interest. Waste legislation and policy of the EU Member States shall apply as a priority in accordance with the waste management hierarchy [18].

In 1973, Denmark passed an environmental protection law which, amongst other things, created the principal foundation for overviewing and controlling waste in the country. Over the following years, the Danish Ministry of the Environment worked towards increasing recycling and reducing resource consumption. In 1978, the world's first law on recycling stating that at least $50 \%$ of all paper and beverage packaging should be recycled was passed. In 1990, the law on recycling was amended. Local authorities were therefore obliged to organise separate collection of paper and glass in all areas except for sparsely-populated areas. Throughout the 1980s, waste in Denmark was still regulated through various legal acts and circulars. However, in 1989, an actual Statuary Order on Waste was implemented in Danish law. This Order established the Ministry of the Environment and the local authorities as the competent authorities regarding waste. Under this order, the local authorities are free to decide on how to collect and manage waste locally; however, they must comply with national targets and objectives. The Statuary Order on Waste was revised and extended in 1993. This revision introduced several municipal obligations in terms of planning as well as data collection and supervision. The first set of municipal waste plans was to be presented 1 January 1996 [66].

In Denmark, commercial waste for recycling is collected and treated on general market conditions. Local authorities are principally organised in intermunicipal companies that own incineration plants, landfills and so forth. Recycling capacity is in many cases secured by agreements with private recycling companies or via intermunicipal companies. In Denmark, economic and political instruments have also been introduced to regulate waste management in a way that it moves upwards in the waste management hierarchy. The first aim was to divert waste from landfills towards incineration. The aim was to protect the groundwater, as well as contribute to the generation of district heating and, later, electricity. In 1987, a landfill tax was introduced. In 1997, this tax was supplemented by a ban on the landfill of all waste that was not considered suitable for recycling or incineration. The landfill tax and the landfill ban are two of the primary drivers for the way in which waste is treated in Denmark [66].

In Denmark, all waste collectors, receivers, exporters and importers of waste must report their wastes data to the Danish Environmental Protection Agency Waste Data System (Danish abbreviation: ADS). It is a mandatory requirement that all reports must state the information about the source of the waste and the receiver of the waste. In addition, for waste from businesses and public institutions then the Central Business Register Number (CVR) and P-unit numbers of that business/institution must be included. The producer of the waste must be stated [67].

A report to the ADS system must contain the following information:

- Quantity

- Waste fraction (comprised of 31 household waste codes and 35 industrial waste codes) 72 , as well as a List of Waste Code (LoW) Code 73.

- Treatment 6 Danish treatment codes, 13 recovery codes (R codes) and 15 disposal codes (D codes). For those actors not treating waste themselves then the expected treatment to which waste is subjected is required to be stated in the report.

- Final treatment. The actors must state whether they subject the waste to a final treatment. Final treatment means that waste is taken out of the waste flow. This may happen, among others, through incineration, landfilling, recycling or export of the waste [67] (p. 51). 
The rules on the Danish Waste Data System (ADS) were described in a stand-alone Statutory Order No. 1306 of 17 December 2012. It is stated in the Order that if businesses do not report in due time then they may be subject to a fine [67].

The environmental impact of Copenhagen Airport is regulated by several authorities through a number of environmental approvals that have been provided under the Danish Environmental Protection Act. The Danish Environmental Protection Agency (DEPA), which is part of the Ministry of Environment and Food, is the agency responsible for national environmental legislation. The second authority is the local Municipality of Tårnby. The Municipality is responsible for local planning issues, including granting land use permits and for taking into consideration other related environmental impacts, that are subject to environmental regulation. The Municipality is also the primary contact point for the public on all matters relating to the environment [62], with exception of noise from air traffic and air quality.

Thus, Copenhagen Airports A/S (CPH) is subject to extensive environment-related regulation, and the starting point for the company's work is always full compliance with all its statutory and regulatory environmental, climate and energy requirements [60]. Historically, Copenhagen Airport has had an environmental policy. An important aim of the policy was that the airport would aim to handle waste in an environmentally responsible manner. In 2010, Copenhagen Airport implemented an updated waste management that covered the period 2011 to 2014. The focus of the 2011 to 2014 waste management plan was:

- Recycling: ensure a more efficient and effective collection of cardboard, paper and plastic bottles;

- Visibility: reducing sorting errors with a more transparent waste system;

- Dynamics: continually adapting waste handling procedures to the changes made at the airport [62] (p. 52).

In 2014, the company defined new strategic targets for three environment-related areas that will also contribute to its responsible growth. The airport has set a target that 50 percent or more of the day-to-day waste generated in the terminal, service and administrative areas at Copenhagen Airport should be recycled by 2020. Furthermore, the airport is aiming to reduce its energy consumption by 20 percent through energy savings (based on 2012 levels) and CPH should be responsible for maximum emissions of $1 \mathrm{~kg}$ of $\mathrm{CO}_{2}$ per passenger by 2020. The company also aims to maintain its Airport Carbon Accreditation at Level 3 or higher [58] (p. 45).

\subsection{Sources and Types of Waste Produced at Copenhagen Airport}

There are two principal sources of waste at Copenhagen Airport: waste from aircraft and the waste arising from ground activities [68]. In terms of responsibility, Copenhagen Airports A/S removes waste from the airport's three passenger terminals, from the company's maintenance facilities and administration buildings. Other firms have the responsibility for the disposal of waste from aircraft and other ground related activities, such as maintenance and flight catering [69].

The separation of waste for subsequent reuse or recycling is a key measure for controlling and reducing the volume of waste disposed by landfill. Waste separation should take place at the source as this is the most economic option. The separation and sorting of the waste at the source provides the opportunity for waste to be reused or recycled and to compost organics. The resorting of waste can therefore reduce the volume of waste disposed by landfill [70]. Importantly, once waste is separated it should not be mixed with other types of waste again [37]. At Copenhagen Airport paper, cardboard, glass and bottles, hazardous waste and refuse-like waste are all collected at the source. Waste that is swept from streets and oil waste originating from sludge-treatment facilities is also collected at the source and is moved directly to an external recipient. The other types of waste are transported to the container site (See Figure 3). These wastes include large incinerable waste, garden and park waste, non-incinerable waste to landfill, iron and metal, electronic scrap, fluorescent and low-energy light bulbs, other hazardous waste, as well as building and construction waste. The latter includes several 
types of waste originating from minor maintenance projects, primarily performed by Copenhagen Airports A/S own staff [59].

Figure 2 shows the waste disposal chain at Copenhagen Airport. As can be seen in Figure 2, the container station plays a critical role acting as the interface point where the diverse types of waste are sorted for either incineration, recycling or disposal by landfill.

The types of waste that are received at the container site are dependent upon current needs and may therefore differ to those types of waste previously mentioned. The container site must essentially receive all types of non-perishable waste or alternatively be able to refer this type of waste to an approved recipient. Copenhagen Airports A/S [71] notes that "it must always be possible to deliver waste not compromised by a local scheme at the container site or in at another site specified by the container site". There are around thirty distinct types of waste generated at the airport and this waste is delivered to eight different firms for processing/handling [69].

\subsection{Total Annual Volumes of Waste Produced at Copenhagen Airport}

As noted earlier, airports generate substantial volumes of waste from the activities performed by the key landside and airside actors at the airport. Currently, there is approximately 12 tonnes of waste produced at Copenhagen Airport each day [61]. According to Copenhagen Airports A/S [12,55] (p. 132), the amount of waste generated at the airport is calculated based on annual statements supplied by the waste recipients used. The calculation comprises waste produced from the day-to-day operation of airport's terminal areas, service areas and administration at Copenhagen Airport. Waste from major building and construction projects is not included. Figure 3 shows the waste disposal chain at Copenhagen Airport. As can be seen in Figure 3, the container station plays a critical role acting as the interface point where the various types of waste are sorted for either incineration, recycling or disposal to landfill.

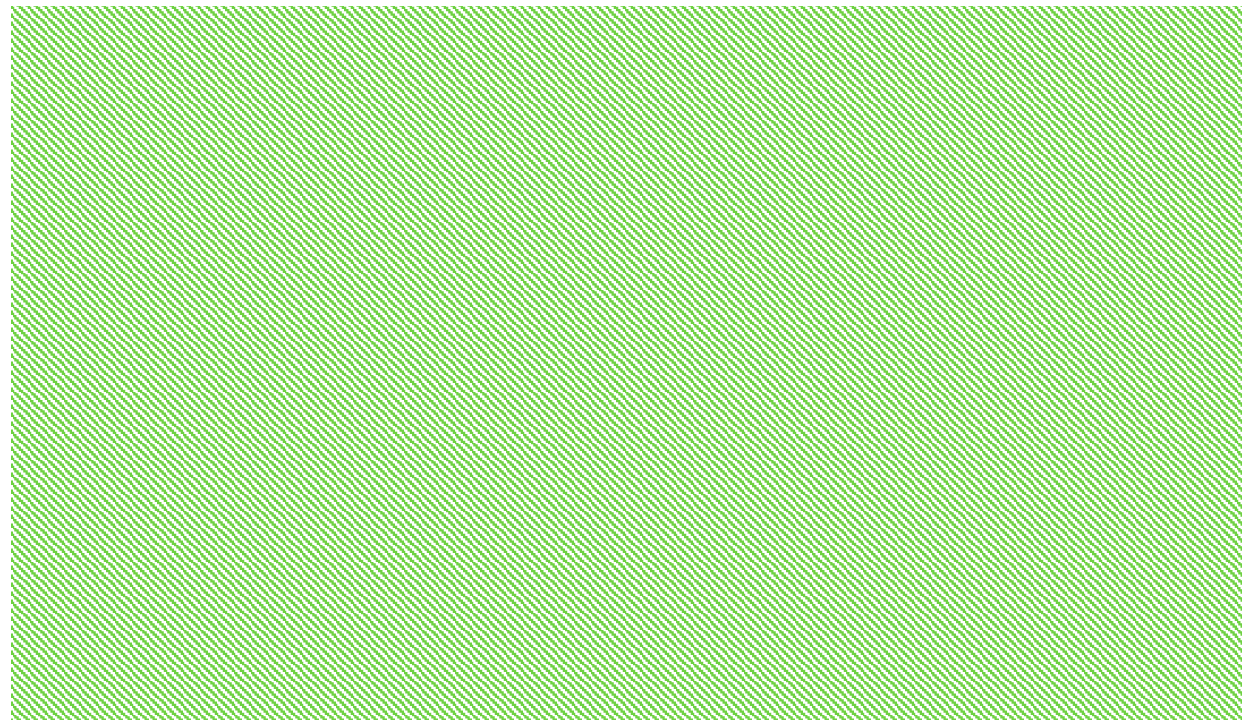

Figure 3. The waste disposal chain at Copenhagen Airport. Source: adapted from [68,69].

Figure 4 shows the total waste generated at Copenhagen Airport from 1997 to 2016. It is important to note that historically, there has been a positive correlation between the volume of waste produced and the number of passengers handled at Copenhagen Airport. As can be observed in Figure 4 in 2011 the total volume of waste increased by $14.6 \%$ year on year, whereas passenger numbers increased by $5.7 \%$ during the same period. Copenhagen Airport A/S have noted that there is no immediate explanation of where the 'extra' waste originated from [72]. 


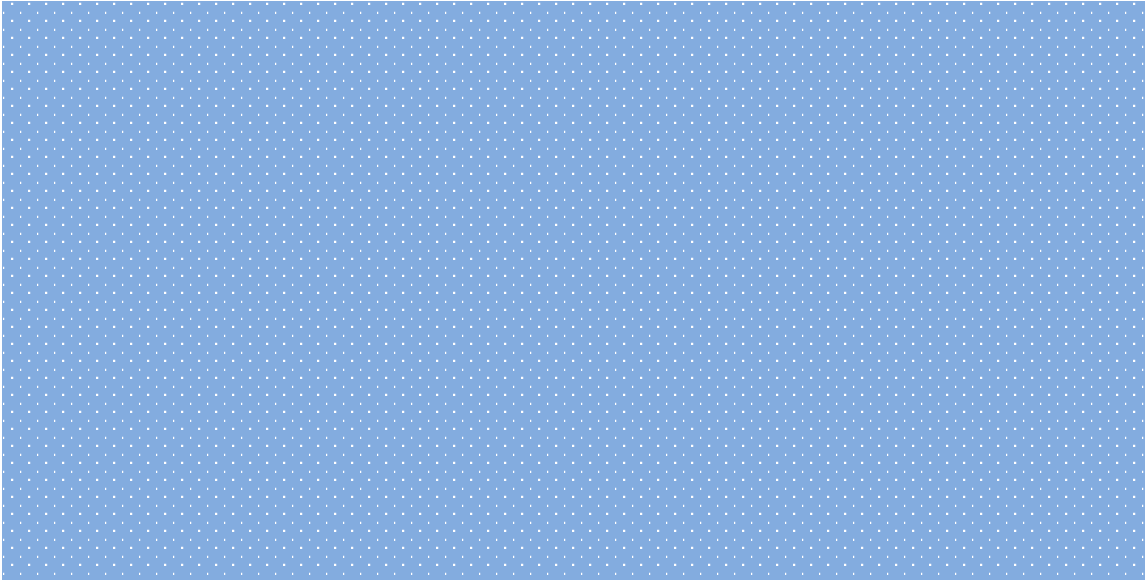

Figure 4. Total annual waste and the annual percentage (\%) change relative to the base year (1999) at Copenhagen Airport: 1999 to 2016. Source: data derived from [12,40,61-64].

Figure 5 shows the annual waste per passenger, while Figure 6 shows the annual waste per aircraft movement (ATM). Figure 7 then shows the annual waste per Work Load Unit (WLU) where one passenger is equal to $100 \mathrm{~kg}$ (this includes the passenger weight and the weight of their baggage), which is based on a total of $100 \mathrm{~kg}$ [73]. In Figure 4, the total annual waste has been consistent since 2011 with an increase noticeable. Figure 5 shows that the waste per passenger has decreased since 2011. The decrease in waste per aircraft in Figure 6 has not been as significant (highlighted by the year on year change), which can be explained by the increase in aircraft size over time. That is, the average capacity of aircraft servicing the airport has increased overtime, so the amount of waste from an average aircraft is coming from more passengers. Scandinavian Airlines (SAS) and Norwegian Air Shuttle, the two largest airlines serving Copenhagen Airport, for example, have increased their aircraft size. SAS has replaced their fleet of Boeing B767 aircraft with larger Airbus A330 and A340 aircraft. Norwegian Air Shuttle has introduced the Boeing B787 on its long-haul, intercontinental services from Copenhagen Airport. Furthermore, Emirates Airline introduced daily Airbus A380 services, the world's largest passenger aircraft, from Dubai to Copenhagen in April 2015. Over the period of high passenger growth rates, that is, 2011 to 2016, the waste per ATM has markedly declined (Figure 6). Figure 7 shows that the annual waste per WLU declined over the period 1999 to 2002 and then rose over the period 2003 to 2007. The total waste per ATM then declined from 2007 to 2009 and then increased in 2010 and 2011.
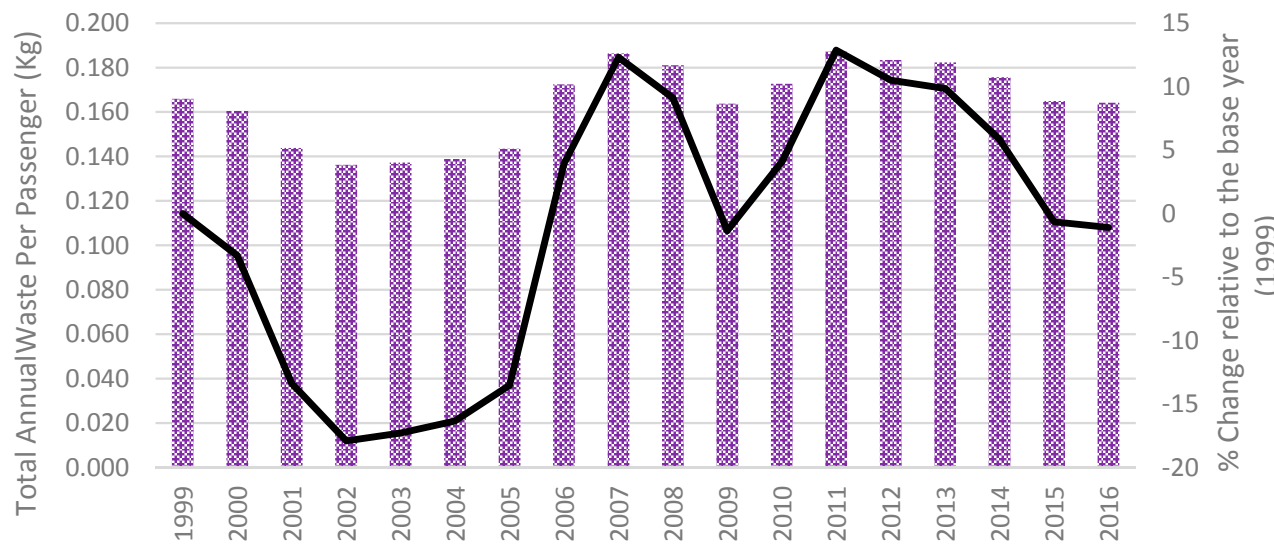

Total Waste Per Passenger

\% change relative to the base year (1999)

Figure 5. Annual waste per passenger and the annual percentage (\%) change relative to the base year (1999) at Copenhagen Airport: 1999 to 2016. Source: data derived from [12,40,61-64]. 


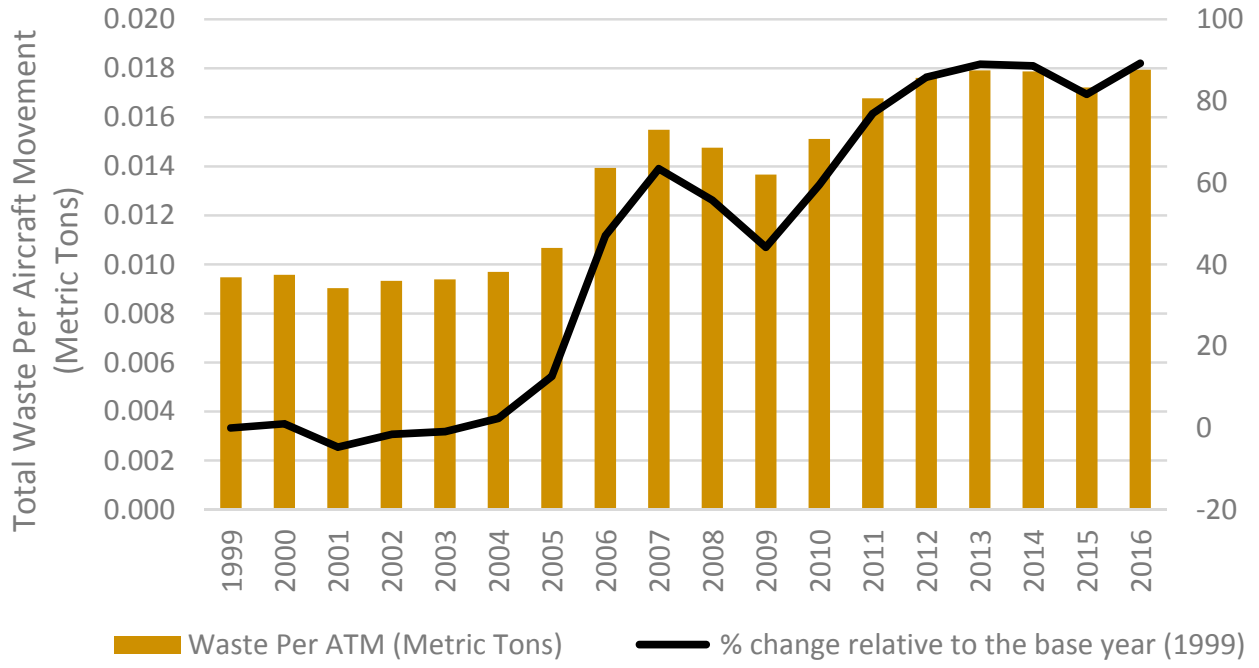

Figure 6. Total annual waste per aircraft movement (ATM) and the annual percentage (\%) change relative to the base year (1999) at Copenhagen Airport: 1999 to 2016. Source: data derived from [12,40,61-64].

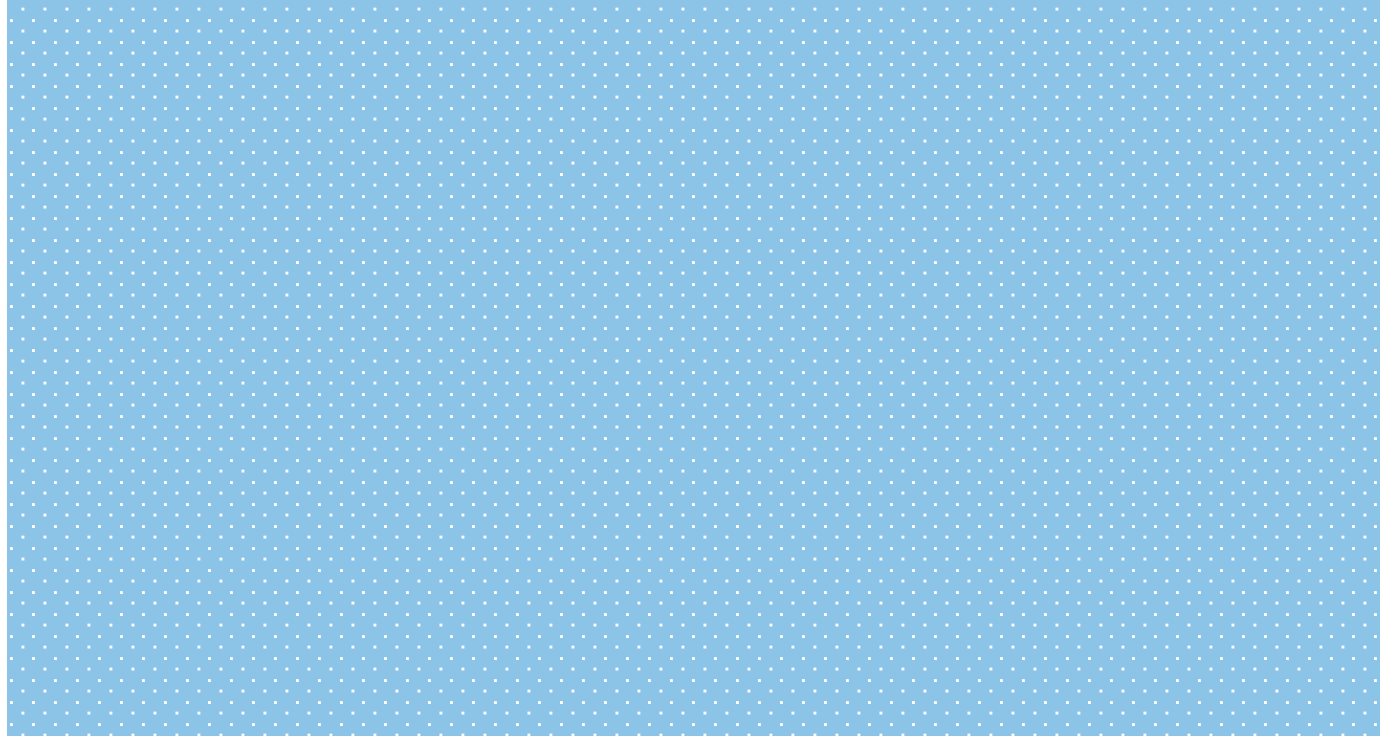

Figure 7. Total annual waste per Work Load Unit (WLU) and the annual percentage (\%) change relative to the base year (1999) at Copenhagen Airport: 1999 to 2016. Source: data derived from [12,40,61-64].

As previously noted, the waste collected at Copenhagen Airport is disposed of by three different methods: incineration, landfill deposit and recycling. Each of these waste disposal methods are examined in the following sections of the paper.

\subsection{Incinerated Waste at Copenhagen Airport}

At Copenhagen Airport, waste that is unable to be recycled is incinerated for district heating and power. This type of waste principally compromises mixed combustible waste that comes from offices, shops, kiosks and the airport's passenger areas [71]. Figure 8 presents the total annual incinerated waste and the annual percentage (\%) change relative to the base year (1999) at Copenhagen Airport from 1999 to 2016. While the quantity of incinerated waste has increased over the entire study's time period, there has also been a small amount of continued growth since 2010. However, factoring in the increase in passenger numbers, the quantity of incinerated waste per passenger has decreased. 


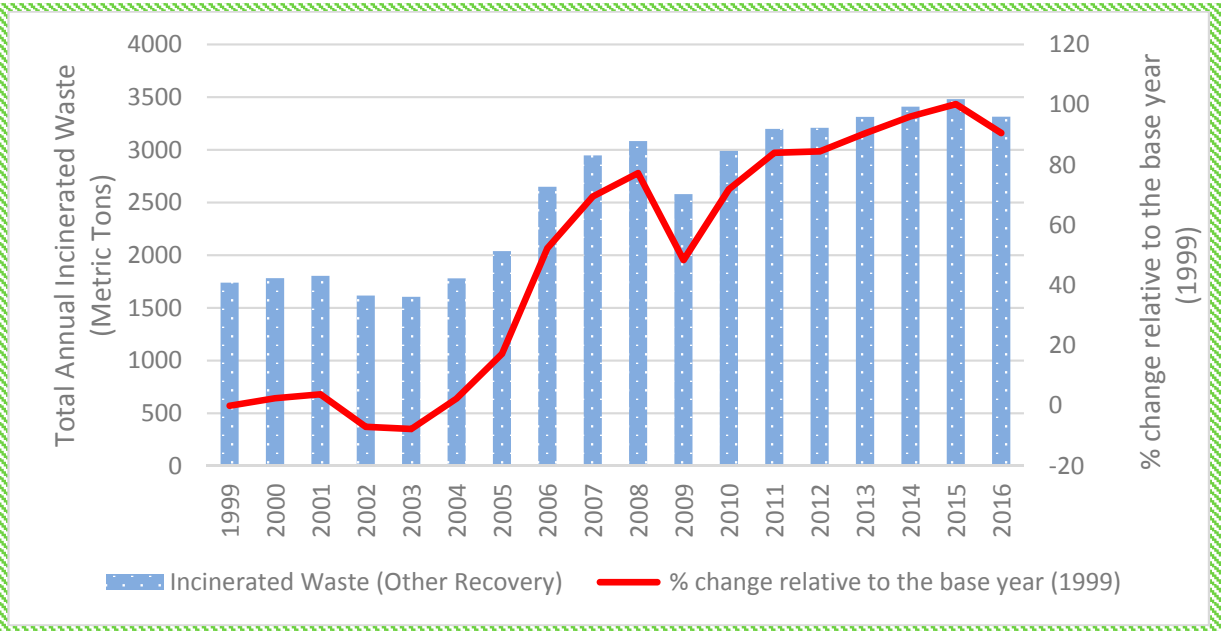

Figure 8. Total annual incinerated waste and the annual percentage (\%) change relative to the base year (1999) at Copenhagen Airport: 1999 to 2016. Source: data derived from [12,40,61-64].

There were a range of factors that influenced the volume of incinerated waste during the review period (1999 to 2016). In 2002, there was a decline in the volume of waste sent for incineration. This was because from 2002, wash water associated with oil spills has been removed for treatment at an external receiver [64]. The volume of waste sent for incineration was 11 percent higher in 2004 than in 2003. This increase was primarily due to the increase in passenger volumes [71]. The increase in incinerated waste in 2005 was principally due to a change in security requirements combined with the increase in passenger numbers [74]. The handling of greater volumes of waste generated on the aircraft serving the airport was the cause of the 30 per cent year-on-year increase in waste for incineration in 2005 [75].

Figure 9 shows the total annual incinerated waste as a percentage of Copenhagen Airport's annual waste from 1999 to 2016. In general, the overall trend is an increasing proportion of incinerated waste. However, if we consider the time since 2008, the proportion of incinerated waste has stagnated at an average of $(76.6 \pm 2.3)$ percent. Interestingly, there has been a significant reduction in 2016, and it will be interesting to see if this trend continues over time. It should be noted that while incineration produce $\mathrm{CO}_{2}$ and other by-products, it is primarily used as a source of heating and power. That is, rather than combusting non-renewable resources (for example, oil and natural gas), these waste by-products from the daily operation of the airport are used to source heating and power.

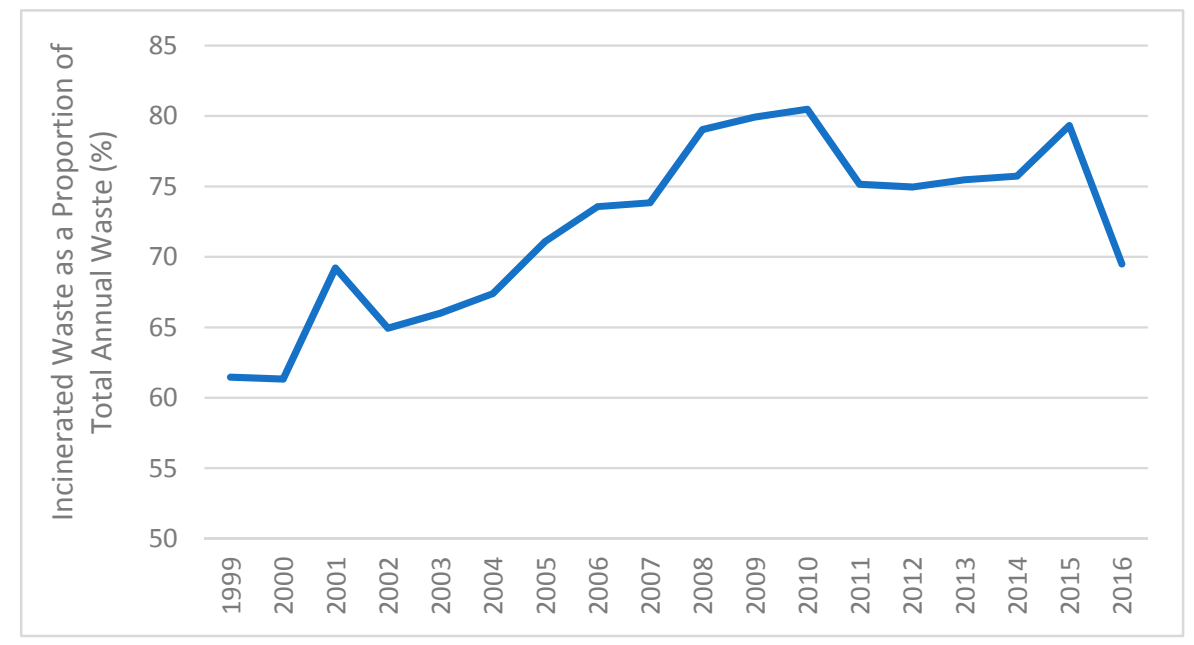

Figure 9. Copenhagen Airport's total annual incinerated waste as a percentage of the total waste: 1999 to 2016. Source: data derived from [12,40,61-64]. 


\subsection{Recycled Waste at Copenhagen Airport}

The recyclable waste generated at Copenhagen Airport is primarily cardboard, paper and iron and other metals. Most of the recyclable waste at the airport is generated continually from airport operations. However, a smaller, but highly variable volume is also generated by various cleaning-up processes undertaken at the airport [61]. Figure 10 depicts the total annual recycled waste and the annual percentage (\%) change relative to the base year (1999) at Copenhagen Airport from 1999 to 2016.

As Figure 10 shows recycled waste volumes have grown in recent years and now comprises around 18 percent of the waste generated at Copenhagen Airport [58]. Like the incinerated waste, there have been a range of factors that have influenced the volume of recycled waste at Copenhagen Airport during the period 1999 to 2016.

The proportion of recycled waste increased in 2000, as Copenhagen Airports A/S started to sort paper and cardboard from the other types of waste collected in the terminals. The waste is sorted by the cleaning staff when they empty refuse bins and during the cleaning of the airport terminals [76]. In 2001, the increase in the volume of recycled waste achieved in previous years was not continued despite increased paper collection in the terminal piers and the establishment of an additional cardboard collection area. This was primarily attributed to a changed reporting method which means that waste that was previously registered as recyclable was subsequently recorded as building and construction waste [68].

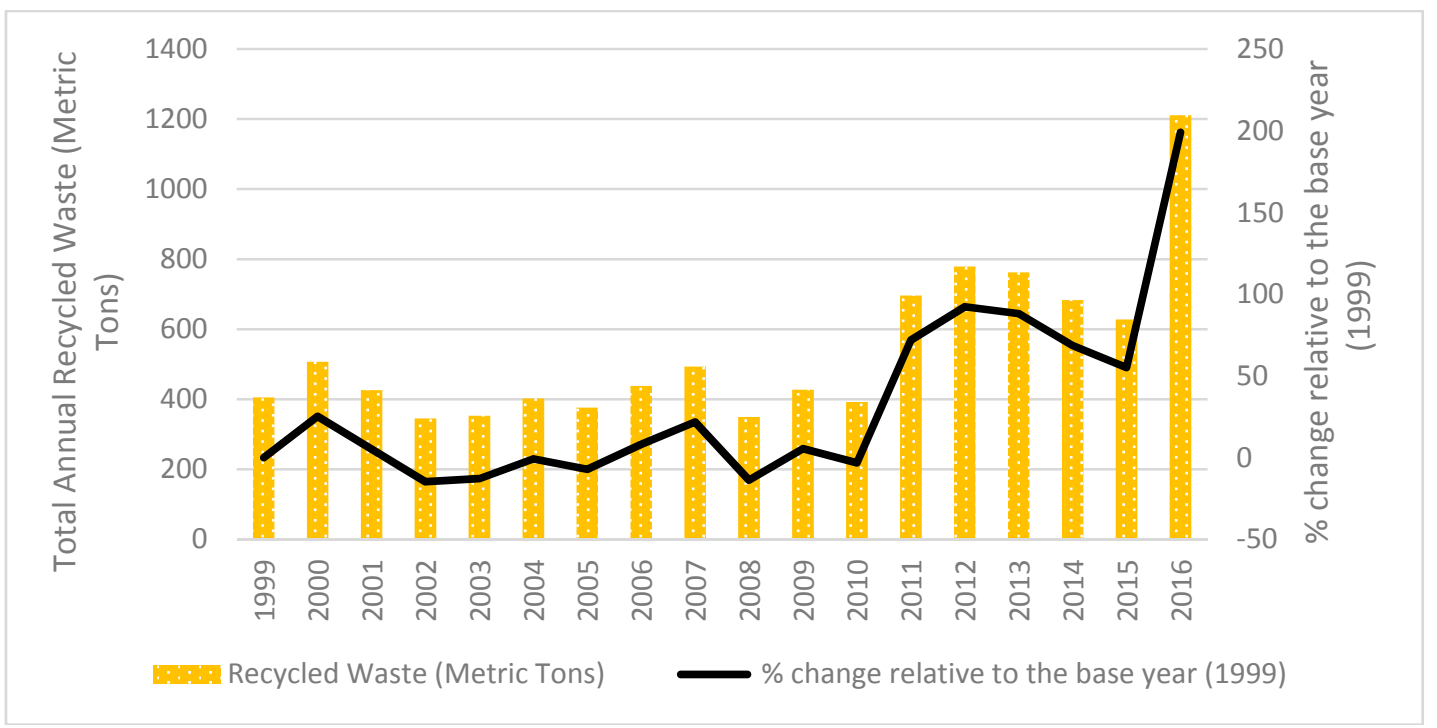

Figure 10. Total annual recycled waste and the annual percentage (\%) change relative to the base year (1999) at Copenhagen Airport: 1999 to 2016. Source: data derived from [12,40,61-64].

In 2004, recycled waste represented around 15.20 percent of the airport's total annual waste. A notable recycling initiative during the year was that 26 tonnes of snow fencing was disposed of through recycling [71]. The volume of recycled waste declined from around 15.20 percent in 2004 to 13.11 percent in 2005. This decline was due to the introduction of stricter security requirements which resulted in the decrease in the total amount of waste collected during 2005 [74].

In 2006 and 2007, the amount of waste gathered and sent for recycling were almost the same levels. In both years the volume of irons and metal collected rose sharply [75]. The volume of cardboard collected and sent for recycling rose sharply in 2006 [63]. In 2008, the amount of recycled waste once again declined on the previous year volumes. During 2008, the amount of iron and metal showed a significant decline following strong increases in 2006 and 2007 [40].

In 2011, Copenhagen Airport maintained a focus on optimising the airport's waste system to ensure that a larger share of waste was recycled. One outcome of this strategy was that the volume of 
recycled newspapers increased from zero to more than 200 tonnes in 2011. The total volume of waste sent for recycling in 2011 increased by 77 percent. This was equivalent to a year-on-year increase of 300 tonnes [72]. In 2012, recycled waste accounted for 18 percent of the airport's total waste volume. The total amount of waste that was sent for recycling in 2012 was 12 percent higher than in 2011. The improved recycling volumes were attributed to an increase in the volumes of iron, metal and cardboard that was sent for recycling at the airport [77]. The initiative represented a statistically significant increase in the average quantity of recycled waste, comparing 1999 to 2010 to 2011 to 2015 (one-tailed $t$-test, assuming equal variance, $p$-value $=1.8 \times 10^{-8}$ ). The increase from 2015 to 2016 is also a significant change (an outlier compared to the "normal" distributions of the previous range of dates).

For each one million additional passengers, Copenhagen Airport estimates that around 140 tonnes of waste will be generated in the airport's terminals. Consequently, the predicted growth in passenger traffic volumes at Copenhagen Airport requires more of the airport's waste handling and logistics services. The airport's waste handling and logistics services must therefore be made more efficient and need to be incorporated into the plans for the proposed expansion of the airport's terminal complex. The airport also intends to work to ensure not only that a substantially greater proportion of the airport's waste is recycled, but also that retailers operating in the airport's shopping centre precinct will implement more efficient processes for the handling and the sorting of waste. In 2013, with these goals in mind, the airport prepared a new five-year plan for waste handling that included a new waste concept. In 2014, the continuing optimisation of waste handling was based on this new waste concept. The total volume of waste generated in 2013 was 4388 tonnes, an increase of 2.5 percent on 2012 volumes. In 2013, 17 percent of the waste generated at the airport was handled as recyclable waste. Both the actual waste volume and the share of recyclable waste showed a slight decrease (Figure 10) [12].

As previously noted, Copenhagen Airport handles a large volume of waste every year. Considering the airport's growth strategy, the airport has recognized that it is important to ensure that as much waste as possible is recycled. In 2014, the airport set a target that at least 50 percent of the waste produced from day-to-day operations of the terminal areas, service areas and administration areas will be recycled by 2020. This target is a significant increase on the 15 percent recycled in 2014 . In 2015, 14 percent of the waste generated from day-to-day operations was recycled. To achieve the recycling target objective (50 percent), the airport authority implemented several waste recycling initiatives across the organization and the airport in 2014 and 2015. The initiatives included the development of a new logistics and waste concept in the airport's shopping centre. This concept makes it easier for the airport's tenants to sort and dispose of their waste as close to the stores location as possible. In addition, restaurants and cafés can also separate their bio-waste, which is collected and subsequently used to produce biogas. The airport authority (CPH A/S) introduced an improved waste sorting concept in 2015 as part of the upgrade of the authority's office building (which was completed in 2015). Despite these waste projects not commencing until late 2015, the airport's waste recycling rate reached 20 percent in the fourth quarter of 2015 [78].

In 2016, the introduction of projects focusing on waste from stores and restaurants continued. This was the principal reason why the volume of waste recycled in 2016 was almost double 2015 volumes [58].

Figure 11 shows the total annual recycled waste as a percentage of Copenhagen Airport's total annual waste from 1999 to 2016. In contrast to the quantity of recycled waste increasing, the proportion or recycled waste has remained constant between 1999 and 2015, with an average value of $(14 \pm 1)$ percent. However, there is a significant jump in 2016, with the proportion increasing to 25 percent, clearly an outlier (more than 3 standard deviations, measured to be 2.5 , from 14 ). 


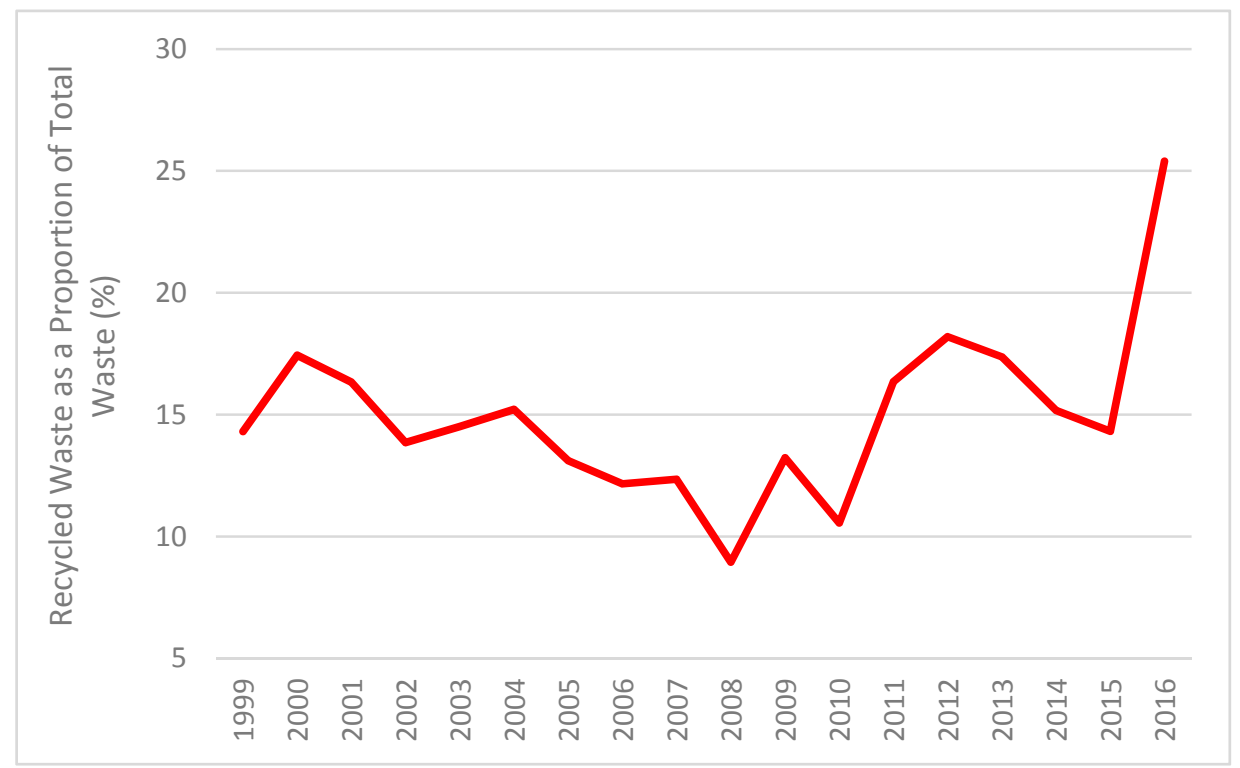

Figure 11. Total annual recycled waste as a percentage of Copenhagen Airport's total waste: 1999 to 2016. Source: data derived from [12,40,61-64].

\subsection{Special Treatment and Landfill Waste at Copenhagen Airport}

Some of the waste generated at Copenhagen Airport contains environmentally hazardous compounds and is therefore not suitable for recycling or ordinary incineration. Consequently, this type of waste must be incinerated at special facilities, such as those provided by "KommuneKemi". Waste for special treatment primarily consists of water that contains a small content of oil and/or soap, for example, waters generated from washing the airport's aircraft stands following oil spills. There are two factors that influence the volume of this waste: the amount of precipitation and the time of year the airport's collection tanks are emptied. Accordingly, there are large fluctuations in the volume of waste that requires special treatment at the airport (Figure 12). In addition, waste that is generated at Copenhagen Airport and which is neither suited for recycling nor for incineration is required to be deposited at a landfill site. This type of waste primarily comes from infrastructure maintenance at the airport and is therefore not influenced by changes in the number of passengers handed at the airport. The largest fraction for disposal to landfills at Copenhagen Airport is waste swept from streets and similar areas and waste vacuumed from the aircraft stands and other similar areas [69]. Some of the waste generated at the airport contains environmentally hazardous compounds and is therefore unsuitable for either recycling or ordinary incineration. This type of waste needs to be processed at special treatment facilities where the waste is incinerated at extra hot temperatures [75]. Figure 12 shows the annual percentage (\%) change relative to the base year (1999) in the special treatment and landfill waste at Copenhagen Airport from 1999 to 2016.

The fluctuations in the volume of waste disposed by Copenhagen Airport over the study period has been due to several key factors. Because of lower building and construction activity at the airport in 2000, the proportion of waste disposed by landfill declined by 4 percent on 1999 volumes. The reduction in building activity resulted in a significant decrease in the amount of soil, dirt and such that was swept up from the airport's roads [76]. The volume of waste disposed by landfill decreased by 34 percent in 2001 (Figure 12) due to the lower levels of building activity at the airport during the year. Furthermore, during 2001, a purification plant located in the airport's fire-drill area was optimized so that the residual products from the fire drills, which comprise oil, water and detergent, were purified using a new filter. This initiative resulted in a lower level of oil waste that requires special treatment [68]. 


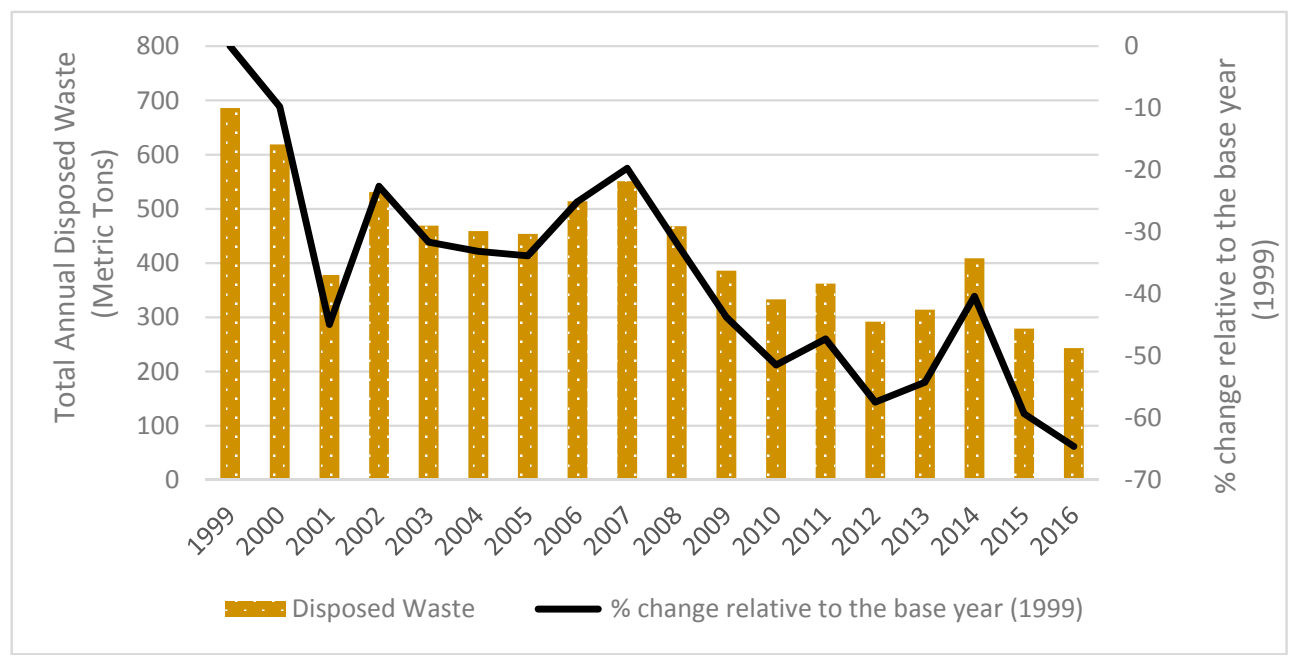

Figure 12. Total annual disposed waste and the annual percentage (\%) change relative to the base year (1999) at Copenhagen Airport: 1999 to 2016. Source: data derived from [12,40,61-64].

Effective in 2002, the wash water arising from oil spills at the airport has been removed for treatment by an external firm. Consequently, this involves a large amount of waste requiring special treatment and this contributed to the increase in disposed waste in 2002 (Figure 12). In 2003, the volume of disposed waste declined dramatically and largely returned to their pre-2000 levels [79]. In 2005, there was an increase in the waste disposed by landfill due to infrastructure maintenance [74]. The volume of waste disposed by landfill declined by around 34 percent in 2008 due to the lower level of activity at the airport [40].

Figure 13 shows the total annual disposed waste as a percentage of Copenhagen Airports annual waste from 1999 to 2016. Although Figure 12 shows a large amount of scatter, the underlying decreasing trend is still clear. When factoring in the increase in passenger numbers, there is a definitive decrease on the amount of landfill waste per passenger. The most significant trend is illustrated in Figure 13, where there is a very significant trend in the reduction of the proportion of waste sent to landfill. This is significant because landfill has negative impacts on the population due to pollution risks $[80,81]$ and exposure to toxic compounds. Hence, by reducing the proportion of waste sent to landfill, the airport has significantly reduced its environmental foot print.

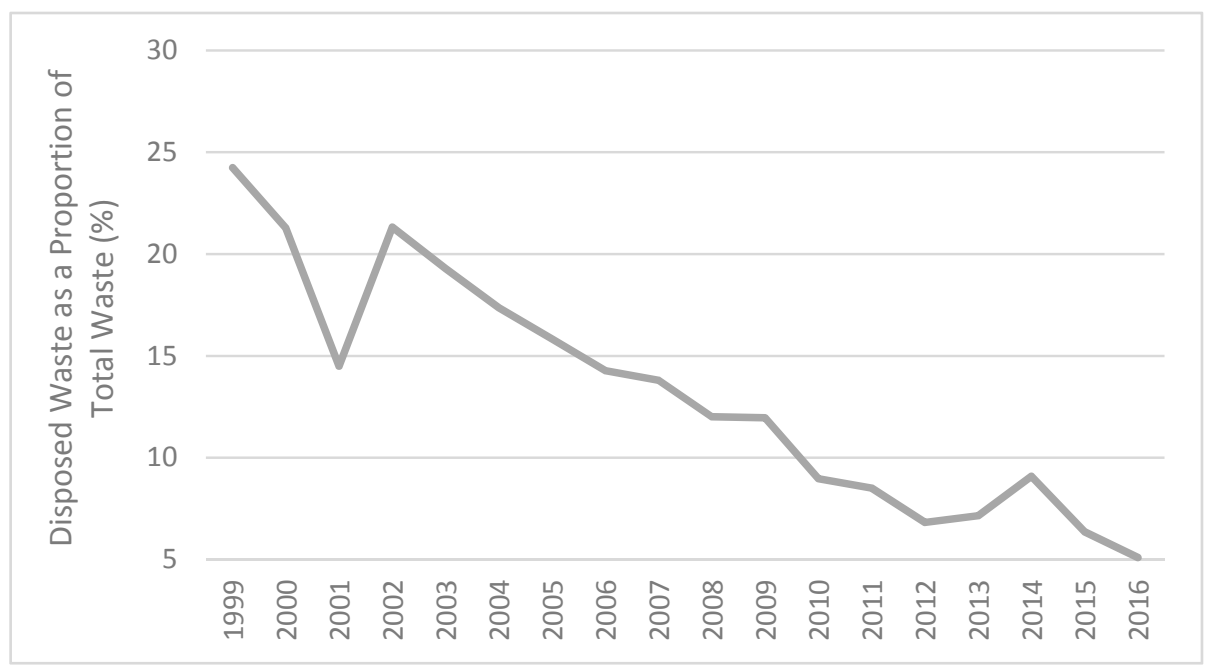

Figure 13. Total annual disposed waste as a proportion of total waste at Copenhagen Airport: 1999 to 2016. Source: data derived from [12,40,58-61]. 


\subsection{Recommendations}

Copenhagen Airport has defined and implemented a clear waste management policy that considers its regulatory obligations and industry best practice. The airport has designed and operates a waste management disposal system that, most importantly, includes the key industry stakeholders, such as the airlines serving the airport. The waste disposal chain includes the appropriate infrastructure and reporting systems. Waste is sorted at the origin. An efficient waste management system aims to prevent the origination of waste in the first instance. Wherever possible, there should be the re-use of packaging materials and so forth. Other initiatives include having a policy on copying and printing of paper and endeavour to ensure that there is a reduction in paper. Secondly, the policy should have as a key aim the minimization of the amount of waste and, most importantly, should include the separation of waste at the source and compacting. Waste can be disposed through incineration (combined with heat production, de-contamination and recycling). Most importantly collaboration with key stakeholders is critical as is raising awareness of the importance to mitigate the amount of waste generated [38].

\subsection{Limitation of the Study}

As noted earlier in the paper, it is a traditional practice to divide an airport into the landside and airside precincts. Both the landside and airside generate wastes. A limitation of the present study was that Copenhagen Airports A/S compiles its waste data at an aggregate airport level and not specifically by the volumes produced on the landside and airside precincts.

\subsection{Future Work}

Logistics and supply chain management are now key aspects for businesses located all around the world [82]. There are discrete supply chains at airports, for example the supply chain of concessionaires and flight catering firms. A potential future study could map the supply and waste disposal chain and identify how it has changed over time. Such a study could examine the impact that changes in packaging and wrapping materials have had on the airport's waste disposal chain.

\section{Conclusions}

The objective of this research was to analyse the sources, types and volumes of waste generated at Copenhagen Airport, as well as the methods used to mitigate the environmental impact of the waste produced at the airport. To achieve this objective, the research was undertaken using an in-depth exploratory case study. The case study data were analysed using document analysis. There are two major sources of waste at Copenhagen Airport: the waste generated from aircraft serving the airport and the waste arising from ground activities undertaken in the land and airside precincts. The recyclable waste primarily consists of cardboard, paper and iron and other metals. The waste that is disposed by incineration principally consists of mixed combustible waste from offices, shops, kiosks and passenger areas at the airport. Waste that requires special treatment primarily consists of water with a small content of oil and/or soap. This may originate from washing aircraft stands following oil spills. Waste that cannot be recycled or incinerated must be deposited in a landfill. This type of waste primarily comes from infrastructure maintenance at the airport. The largest fraction for disposal to landfills is waste that is swept from streets and similar areas and waste vacuumed from aircraft stands and similar areas.

During the study period (1999 to 2016), the annual quantities of waste generated increased from 2830 metric tons in 1999 to 4768 metric tons in 2016. At the time of the present study, Copenhagen Airport is handling around 13 metric tons of waste per day. The annual volumes of waste generated at Copenhagen Airport have been influenced by the airport's growth in both passengers and aircraft movements. During periods of depressed passenger demand, such as post 
September 11, 2001 and the 2008 Global Financial Crisis, the total annual volumes declined due to the smaller number of passengers and aircraft using the airport.

The responsibility for handling the waste generated at the airport is shared by Copenhagen Airports A/S, the airport operator and by those firms, such as flight catering centres and the maintenance organization, who generate waste from the provision of aircraft and ground-related services. Waste is sorted at the origin wherever possible. The swept waste from airport streets and from sludge treatment is processed by an external party. The waste generated in the passenger terminals, Copenhagen Airports A/S administrative and maintenance facilities is processed at the airport container station. The bulk of the waste is incinerated or recycled. Over the study period, around $72.13 \%$ of the total waste was incinerated, around $14.93 \%$ was recycled and around $12.93 \%$ was disposed by landfill. Importantly, disposal of waste by landfill is viewed as the least desirable waste disposal option, and from 2002 to 2016, the annual volume of landfill waste at Copenhagen Airport has been declining, with just 5.06 percent of the total waste disposed by this method in 2016 .

Airlines, flight catering centres and other key actors operating at Copenhagen Airport are responsible for their waste management. The environmental impact of waste at Copenhagen Airport is mitigated through recycling and from incineration. The incinerated waste is used for district heating.

As previously noted, waste is generated in both the airside and landside precincts at Copenhagen Airport. It was not possible to analyse the trends in these discrete areas as the annual waste data are based on the aggregate waste volumes generated at the airport.

Acknowledgments: The authors would like to express their sincere gratitude to Copenhagen Airports A/S for the permission to use the airport's annual environmental performance data.

Author Contributions: Glenn Baxter conceived the paper and wrote the first draft paper. All authors contributed equally to the data analysis and editing of the manuscript.

Conflicts of Interest: The authors declare no conflict of interest.

\section{References}

1. Ferrulli, P. Green airport design evaluation (GrADE)—Methods and tools improving infrastructure planning. Transp. Res. Procedia 2016, 14, 3781-3790. [CrossRef]

2. Allett, T. Alternative Power, Airports International, 12 September. Available online: http://www. airportsinternational.com/2011/09/alternative-power/6380 (accessed on 9 September 2017).

3. Mehta, P. Aviation waste management: An insight. Int. J. Environ. Sci. 2015, 5, 179-186.

4. Oto, N.; Cobanoglu, N.; Geray, C. Education for sustainable airports. Procedia-Soc. Behav. Sci. 2012, 47, $1164-1173$. [CrossRef]

5. Vanker, S.; Enneveer, M.; Mäsak, M. Implementation of environmentally friendly measures at Tallinn Airport. Aviation 2013, 17, 14-21. [CrossRef]

6. Giustozzi, F.; Toraldo, E.; Crispino, M. Recycled airport pavements for achieving environmental sustainability: An Italian case study. Resour. Conserv. Recycl. 2012, 68, 67-75. [CrossRef]

7. Dimitriou, D.J.; Voskaki, A.J. Regional airports' environmental management: Key messages from the evaluation of ten European airports. In Regional Airports; Postorino, M.N., Ed.; WIT Press: Southampton, UK, 2011; pp. 73-86.

8. Edwards, B. The Modern Airport Terminal: New Approaches to Airport Architecture, 2nd ed.; Spon Press: Abingdon, UK, 2005.

9. Parameshwar, H.K. Solid waste management in airports: A case study of Bangalore International Airport. In Proceedings of the International Conference on Green Technology and Environmental Conservation (GTEC-2011), Chennai, India, 15-17 December 2011; pp. 152-158.

10. Pitt, M.; Smith, A. Waste management efficiency at UK airports. J. Air Transp. Manag. 2003, 9, $103-111$. [CrossRef]

11. Pitt, M.; Smith, A. An assessment of waste management efficiency at BAA airports. Constr. Manag. Econ. 2003, 21, 421-431. [CrossRef] 
12. Copenhagen Airports A/S. Group Annual Report Facts and Figures Copenhagen Airports A/S 2014. Available online: https://www.cph.dk/globalassets/5.-om-cph/investor/koncernarsrapporter/groupannual-report-2015.pdf (accessed on 20 September 2017).

13. Department of Economic and Social Affairs of the United Nations Secretariat. Country Classification. Available online: http://www.un.org/en/development/desa/policy/wesp/wesp_current/2014wesp_ country_classification.pdf (accessed on 27 January 2018).

14. Davies, A.R. The Geographies of Garbage Governance: Interventions, Interactions and Outcomes; Routledge: Abingdon, UK, 2016.

15. Zhu, D.; Asnani, P.U.; Zurbrugg, C.; Anapolsky, S.; Mani, S. Improving Municipal Solid Waste Management in India: A Sourcebook for Policy Makers and Practitioners; The World Bank: Washington, DC, USA, 2008.

16. Güren, S. Sustainable waste management. In Handbook of Research on Developing Sustainable Value in Economics, Finance, and Marketing; Akkucuk, U., Ed.; Business Science Reference: Hershey, PA, USA, 2015; pp. 141-156.

17. Manahan, S.E. Fundamentals of Environmental Chemistry, 3rd ed.; CRC Press: Boca Raton, FL, USA, 2011.

18. European Commission. Directive 2008/98/EC on Waste (Waste Framework Directive). Available online: http:/ / ec.europa.eu/environment/waste/framework/ (accessed on 24 January 2018).

19. Atkin, P.; Hershkowitz, A.; Hoover, D. Trash Landings: How Airlines and Airports can Clean up Their Recycling Programs. Available online: https://www.nrdc.org/cities/recycling/airline/airline.pdf (accessed on 29 September 2017).

20. Thomas, C.; Hooper, P. Sustainable development and environmental capacity of airports. In Airport Operations, 3rd ed.; Ashford, N.J., Stanton, H.P.M., Moore, C.A., Coutu, P., Beasley, J.R., Eds.; McGraw-Hill: New York, NY, USA, 2013; pp. 553-578.

21. Rossi Dal, P.F. EU Legal Framework for Safeguarding Air Passenger Rights; Springer International Publishing: Cham, Switzerland, 2015.

22. Baxter, G.; Kourousis, K. Temperature controlled aircraft unit load devices: The technological response to growing global air cargo cool chain requirements. J. Technol. Manag. Innov. 2015, 10, 157-172. [CrossRef]

23. London Stansted Airport. Making a Material Difference: London Stansted Airport Waste Management Strategy 2010-2015. Available online: http:/ / mag-umbraco-media-live.s3.amazonaws.com/1096/stalwastestrategy_ stn.pdf (accessed on 29 September 2017).

24. United States Federal Aviation Administration. Recycling, Reuse and Waste Reduction at Airports: A Synthesis Document. Available online: https:/ /www.faa.gov/airports/resources/publications/reports / environmental/media/RecyclingSynthesis2013.pdf (accessed on 12 September 2017).

25. Graham, A. Managing Airports: An International Perspective, 4th ed.; Routledge: Abingdon, UK, 2014.

26. Baxter, G.; Wild, G.; Sabatini, R. A sustainable approach to airport design and operations: A case study of Munich Airport. In Proceedings of the Practical Response to Climate Change (PRCC) 2014 Conference, Melbourne, Victoria, Australia, 25-27 November 2014; Engineers Australia: Barton, Australia, 2014; pp. 227-237.

27. Janić, M. The Sustainability of Air Transportation: A Quantitative Analysis and Assessment; Ashgate Publishing: Aldershot, UK, 2007.

28. Brown, D.T. Tourism's wasteful ways. In The Routledge Handbook of Tourism and the Environment; Holden, A., Fennell, D.A., Eds.; Routledge: Abingdon, UK, 2013; pp. 460-493.

29. Torretta, V.; Ferronato, N.; Katsoyiannis, I.A.; Tolkou, A.K.; Airoldi, M. Novel and conventional technologies for landfill leachates treatment: A review. Sustainability 2017, 9, 9. [CrossRef]

30. Culberson, S.D. Environmental impact of airports. In Airport Engineering: Planning, Design, and Development of 21st Century Airports, 4th ed.; Ashford, N.J., Mumayiz, S.A., Wright, P.H., Eds.; John Wiley and Sons: Hoboken, NJ, USA, 2011; pp. 704-738.

31. Chandrappa, R.; Das, D.B. Solid Waste Management: Principles and Practice; Springer: Heidelberg, Germany, 2012.

32. Kazda, T.; Caves, B.; Kamenický, M. Environmental control. In Airport Design and Operation, 3rd ed.; Kazda, A., Caves, R.E., Eds.; Emerald Group Publishing: Bingley, UK, 2015; pp. 457-500.

33. Pitt, M.; Brown, A.; Smith, A. Waste management at airports. Facilities 2002, 20, 198-207. [CrossRef]

34. Hooper, P.; Heath, B.; Maughan, J. Environmental management and the aviation industry. In Towards Sustainable Aviation; Upham, P., Maughan, J., Raper, D., Thomas, C., Eds.; Earthscan Publications: London, UK, 2003; pp. 115-130.

35. Janić, M. Greening Airports: Advanced Technology and Operations; Springer: London, UK, 2011.

36. Eriksson, O. Energy and waste management. Energies 2017, 10, 1072. [CrossRef] 
37. Arushanyan, Y.; Björklund, A.; Eriksson, O.; Finnveden, G.; Ljunggren Söderman, M.; Sundqvist, J.O.; Stenmarck, Å. Environmental assessment of possible future waste management scenarios. Energies 2017, 10, 247. [CrossRef]

38. Fleuti, E. Waste Management, Paper presented at the 2nd ACI Airport Environment Seminar, Quito, Ecuador, 24-25 November. Available online: http:/ / www.aci.aero/Media/aci/file/2008\%20Events/Envirnonmental\% 20Colloquium/presentations\%20pdf/42\%20fleuti\%20WasteMgmt.pdf (accessed on 27 September 2017).

39. Spilsbury, L. Waste and Recycling Challenges; The Rosen Publishing Group: New York, NY, USA, 2010.

40. Carysforth, C.; Neild, M. GCSE Applied Business for Edexcel: Double Award; Heinemann Publishers: Oxford, UK, 2002.

41. Copenhagen Airports A/S. Environmental Report 2008. Available online: https://www.cph.dk/contentassets/ fe47a2fb90bd4688a72aa2987119d645/miljo2008_uk.pdf (accessed on 20 September 2017).

42. Guyer, J.P. Engineering Soundbite: Solid Waste Incineration; Amazon Digital Services, Inc.: Seattle, WA, USA, 2011.

43. McDougall, F.R.; White, P.R.; Franke, M.; Hindle, P. Integrated Solid Waste Management: A Life Cycle Inventory; Blackwell Science: Oxford, UK, 2007.

44. Scragg, A.H. Biofuels: Production, Application and Development; CABI: Wallingford, UK, 2009.

45. Elliot, J.; Holland, J.; Thomson, R. Longitudinal and panel studies. In The SAGE Handbook of Social Research Methods; Alasuutari, P., Bickman, L., Brannen, J., Eds.; SAGE: London, UK, 2008; pp. 228-248.

46. Bartlett, L.; Vavrus, F. Rethinking Case Study Research: A Comparative Approach; Routledge: New York, NY, USA, 2017.

47. Beach, D.; Pedersen, R.B. Causal Case Study Methods: Foundations and Guidelines for Comparing, Matching, and Tracing; The University of Michigan Press: Ann Arbor, MI, USA, 2018.

48. Yin, R.K. Case Study Research: Design and Methods, 6th ed.; SAGE: Thousand Oaks, CA, USA, 2017.

49. O'Leary, Z. The Essential Guide to Doing Research; SAGE: London, UK, 2004.

50. Fulcher, J.; Scott, J. Sociology, 4th ed.; Oxford University Press: Oxford, UK, 2011.

51. Scott, J.; Marshall, G. A Dictionary of Sociology, 3rd ed.; Oxford University Press: Oxford, UK, 2009.

52. Plewa, F.J., Jr.; Friedlob, G.T. Understanding Cash Flow; John Wiley and Sons: New York, NY, USA, 1995.

53. Sinha, G. Financial Statement Analysis, 2nd ed.; PHI Learning: New Dehli, India, 2012.

54. Patel, B. Fundamentals of Financial Management; Vikas Publishing House: Noida, India, 2014.

55. Copenhagen Airports A/S. About CPH: A Quick Overview. Available online: https://www.cph.dk/en/ legacy/about-cph-old/profile/Facts-about-CPH/A-quick-overview/ (accessed on 29 September 2017).

56. Star Alliance. Destinations. Available online: http://www.staralliance.com/en/destinations (accessed on 29 September 2017).

57. Copenhagen Airports A/S. About CPH: Employees. Available online: https://www.cph.dk/en/legacy/ about-cph-old/csr/Employees / (accessed on 29 September 2017).

58. Copenhagen Airports A/S. Group Annual Report: Facts and Figures 2016. Available online: https:/ /www.cph. dk/globalassets/5.-om-cph/6.-investor/cph-annual-report-2016-uk_28mb.pdf (accessed on 29 September 2017).

59. European Investment Bank. Environmental and Social Data Sheet: CPH (Copenhagen) Airport Expansion TEN-T. Available online: http:/ / www.eib.org/infocentre/register/all/69558856.pdf (accessed on 29 September 2017).

60. Bartsch, R.I.C. International Aviation Law: A Practical Guide; Routledge: Abingdon, UK, 2016.

61. Copenhagen Airports A/S. About CPH: Waste. Available online: https://www.cph.dk/en/about-cph/dit$\mathrm{cph} /$ nabo/miljo/waste/ (accessed on 30 September 2017).

62. Copenhagen Airports A/S. CPH and Society 2010. Available online: https://www.cph.dk/globalassets/5. -om-cph/csr/reports/csr2010.pdf (accessed on 20 September 2017).

63. Copenhagen Airports A/S. Copenhagen Airports A/S Environmental Report 2006. Available online: https:/ / www.cph.dk/contentassets/fe47a2fb90bd4688a72aa2987119d645/miljo2006_uk.pdf (accessed on 20 September 2017).

64. Copenhagen Airports A/S. Copenhagen Airports A/S Environmental Report 2002. Available online: https:/ / www.cph.dk/contentassets/fe47a2fb90bd4688a72aa2987119d645/miljo2002_uk.pdf (accessed on 20 September 2017).

65. Ministry of Foreign Affairs of Denmark. Denmark in the EU. Available online: http://um.dk/en/foreignpolicy/denmark-in-the-eu/ (accessed on 25 January 2018).

66. Waste and Resource Network Denmark. Waste Regulation in Denmark. Available online: https:/ / dakofa. com/element/test-article-today/ (accessed on 25 January 2018). 
67. Danish Environmental Protection Agency. Waste Statistics 2015. Available online: https://www2.mst.dk/ Udgiv/publications/2017/08/978-87-93614-20-8.pdf (accessed on 27 January 2018).

68. Copenhagen Airports A/S. Copenhagen Airports A/S Environmental Report 2001. Available online: https:/ / www.cph.dk/contentassets / fe47a2fb90bd4688a72aa2987119d645/miljo2001_uk.pdf (accessed on 20 September 2017).

69. Copenhagen Airports A/S. About CPH: Waste Handling. Available online: https://www.cph.dk/en/about$\mathrm{cph} /$ dit-cph/nabo/miljo/waste/waste-handling/ (accessed on 30 September 2017).

70. Allen, A.; Taylor, R. Waste disposal and landfill: Control and protection. In Protecting Groundwater for Health: Managing the Quality of Drinking-Water Sources; Schmoll, O., Howard, G., Chilton, J., Chorus, I., Eds.; IWA Publishing: London, UK, 2006; pp. 361-372.

71. Copenhagen Airports A/S. Copenhagen Airports A/S Environmental Report 2004. Available online: https:/ / www.cph.dk/contentassets / fe47a2fb90bd4688a72aa2987119d645/miljo2004_uk.pdf (accessed on 20 September 2017).

72. Copenhagen Airports A/S. CPH and Society 2011. Available online: https://www.cph.dk/globalassets/5. -om-cph/csr/reports/csr2011.pdf (accessed on 20 September 2017).

73. Doganis, R. The Airport Business; Routledge: Abingdon, UK, 2005.

74. Copenhagen Airports A/S. Copenhagen Airports A/S Environmental Report 2005. Available online: https:/ / www.cph.dk/contentassets/fe47a2fb90bd4688a72aa2987119d645/miljo2005_uk.pdf (accessed on 20 September 2017).

75. Copenhagen Airports A/S. Environmental Report 2007. Available online: https://www.cph.dk/contentassets/ fe47a2fb90bd4688a72aa2987119d645/miljo2007_uk.pdf (accessed on 20 September 2017).

76. Copenhagen Airports A/S. Copenhagen Airports A/S Environmental Report 2000. Available online: https: / / www.cph.dk/contentassets/fe47a2fb90bd4688a72aa2987119d645/miljo2000_uk.pdf (accessed on 20 September 2017).

77. Copenhagen Airports A/S. CPH and Society 2012. Available online: https://www.cph.dk/globalassets/5.-omcph/investor/koncernarsrapporter/csr/cph_samfundet13_uk_final.pdf (accessed on 20 September 2017).

78. Copenhagen Airports A/S. Group Annual Report: Facts and Figures 2015. Available online: https:/ / www.cph. $\mathrm{dk} /$ globalassets/5.-om-cph/investor/koncernarsrapporter/group-annual-report-2015.pdf (accessed on 29 September 2017).

79. Copenhagen Airports A/S. Copenhagen Airports A/S Environmental Report 2003. Available online: https:/ / www.cph.dk/contentassets/fe47a2fb90bd4688a72aa2987119d645/miljo2003_uk.pdf (accessed on 20 September 2017).

80. Williams, P.T. Waste Treatment and Disposal, 2nd ed.; John Wiley and Sons: Chichester, UK, 2005.

81. Daniels, T. Environmental Planning Handbook for Sustainable Communities and Regions, 2nd ed.; Routledge: Abingdon, UK, 2017.

82. Mangan, J.; Lalwani, C. Global Logistics and Supply Chain Management, 3rd ed.; John Wiley and Sons: Chichester, UK, 2016.

(C) 2018 by the authors. Licensee MDPI, Basel, Switzerland. This article is an open access article distributed under the terms and conditions of the Creative Commons Attribution (CC BY) license (http://creativecommons.org/licenses/by/4.0/). 